\title{
WestVirginiaUniversity
}

THE RESEARCH REPOSITORY @ WVU

Graduate Theses, Dissertations, and Problem Reports

2012

\section{Effect of Engineered Metal-Oxide Nanomaterials on Bacterial Viability}

Lina Cui

West Virginia University

Follow this and additional works at: https://researchrepository.wvu.edu/etd

\section{Recommended Citation}

Cui, Lina, "Effect of Engineered Metal-Oxide Nanomaterials on Bacterial Viability" (2012). Graduate Theses, Dissertations, and Problem Reports. 4844.

https://researchrepository.wvu.edu/etd/4844

This Thesis is protected by copyright and/or related rights. It has been brought to you by the The Research Repository @ WVU with permission from the rights-holder(s). You are free to use this Thesis in any way that is permitted by the copyright and related rights legislation that applies to your use. For other uses you must obtain permission from the rights-holder(s) directly, unless additional rights are indicated by a Creative Commons license in the record and/ or on the work itself. This Thesis has been accepted for inclusion in WVU Graduate Theses, Dissertations, and Problem Reports collection by an authorized administrator of The Research Repository @ WVU. For more information, please contact researchrepository@mail.wvu.edu. 


\title{
Effect of Engineered Metal-Oxide Nanomaterials on Bacterial Viability
}

\author{
Lina Cui \\ Thesis submitted to the \\ BENJAMINE M. STATLER College of Engineering and Mineral Resources \\ West Virginia University
}

In partial fulfillment of the requirements for the degree of
Master of Science

In

Civil and Environmental Engineering

Lian-Shin Lin, Ph.D., P.E., Chair

Jennifer Weidhaas, Ph.D., P.E.

Nick Wu, Ph.D.

Department of Civil and Environmental Engineering

West Virginia University

Morgantown, West Virginia

2012

Keywords: Photocatalytic Inactivation, Metal-Oxide Nanomaterials, Reactive Oxygen Species 


\section{Abstract}

\section{Effect of Engineered Metal-Oxide Nanomaterials on Bacterial Viability}

\section{Lina Cui}

The occurrence of emerging or newly identified contaminants in our water resources is of rising concern for human health and the environment. Nanomaterials rise to be among the major emerging contaminants in recent years because of their broad applications. The existing conventional water and wastewater treatment plants are not designed for removal of these contaminants. To date, little is known about the fate and impacts of these contaminants in the water systems.

Engineered nanomaterials such as titanium dioxide $\left(\mathrm{TiO}_{2}\right)$ are known to produce reactive oxygen species (ROS) under irradiation of ultraviolet or visible light. A sub-lethal level of ROS could trigger microbial defense mechanisms which protect microorganisms from environmental oxidative stress and its damages. This microbial resistance to environmental oxidative stress may increase the threat to human health. Conversely, excessive amounts of ROS have a cytotoxic effect on microorganisms by causing membrane and DNA damages. The damages can reduce microbial viability, making the microorganisms more susceptible to other oxidants such as chemical disinfectants used for wastewater disinfection. As a result, the interactions of nanomaterials with microorganisms are expected to affect the efficiency of chemical disinfection. Understanding the potential of ROS generation for nanomaterials and its relationship with bacterial inactivation is important to track the impact of nanomaterials in the water purification systems. In this thesis, the relationships between reactive oxygen species production rates and Escherichia coli inactivation rates of five engineered titanium-oxide nanomaterials with a range of shapes, sizes, crystal structures, and chemical composition were studied. Hydroxyl radical $(\cdot \mathrm{OH})$ and superoxide ion $\left(\mathrm{O}_{2}{ }^{-}\right)$production rates of the nanomaterials under long-UV irradiation were estimated using species-selective probe molecules and spectrophotometric measurements. The bacterial inactivation rates were estimated by a series-event kinetic model and were compared across the five materials on a per unit surface area basis. Photo-energy utilization 
efficiency of these nanomaterials for ROS production varied with not only with the type of materials but also with irradiation intensity and nanomaterial loading. Degussa P25 was found to have a distinctly different correlation between $\cdot \mathrm{OH}$ production rate and bacterial inactivation rate from that of the remaining nanomaterials. The results support the use of a metric of multiple ROS or biological responses for more accurately characterizing and predicting disinfection efficiency or other cytotoxic effects of metal-oxide nanomaterials across a range of physicochemical properties. 


\section{Acknowledgement}

My very sincere appreciation is extended to my advisor, Dr. Lian-Shin Lin, for his persistent encouragement, patience, inspiration, trust, guidance and financial assistance for this research project. I would like to thank Dr. Jennifer Weidhaas and Dr. Nick Wu for their devoted support for my master study.

I am thankful to Dr. Kathleen Brundage for the technical assistance she provided during the use of West Virginia University Flow Cytometry Core Facility. Special thanks due to Dr. Hoil Park, Dr. Karen Buzby, and Mr. William Ravenscroft for their valuable advice and help during the project.

I would like to thank graduate students, Hang Li, Maggie Wei, Shilpa Bhojappa, Meilin Liu, Paola Correa, Ning Zhang, Isabel Cardona, Yunshun Chen, Chenjie Wu, Dongyang Deng, Mehrdad Mohtadi, Pujya W. Gautam, Thomas Richard for their friendship and help during the project.

Finally, I am sincerely grateful to Kevin He, Chuck \& Mary Maggio, Chuck \& Ginny Lewis and HOPE family for their spiritual love and encouragement during my entire study in Morgantown. 


\section{Table of Contents}

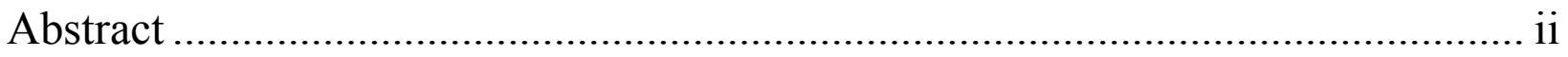

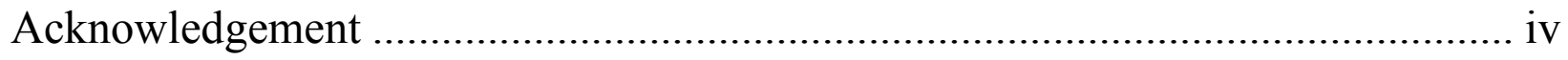

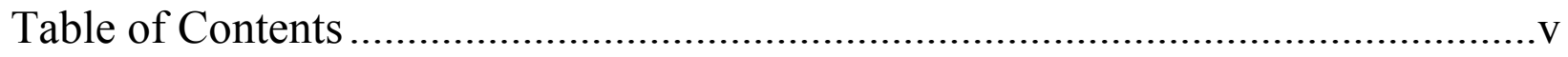

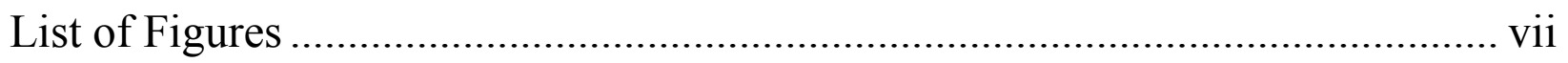

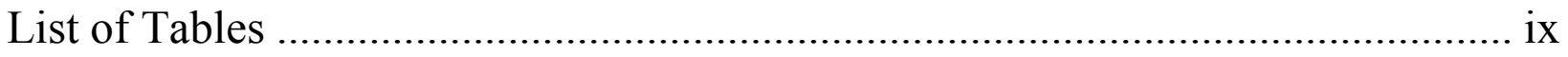

Chapter 1: Introduction ..............................................................................................1

1.1 Emerging contaminants and research significance ……................................................ 1

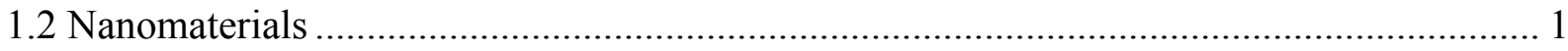

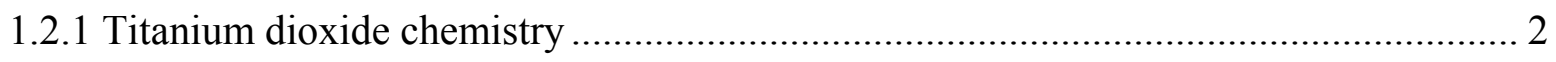

1.2.2 Antimicrobial effects characterization.................................................................... 3

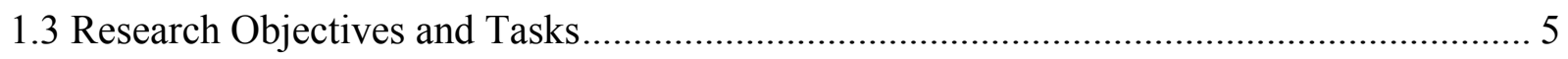

Chapter 2: Methods and Materials ...................................................................8

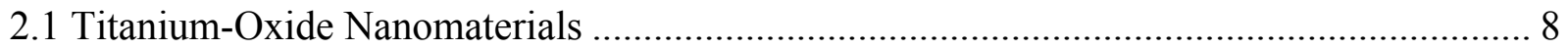

2.2 Hydroxyl Radical Production Rate Estimation ................................................................ 9

2.3 Superoxide Ion Production Rate Estimation .............................................................. 10

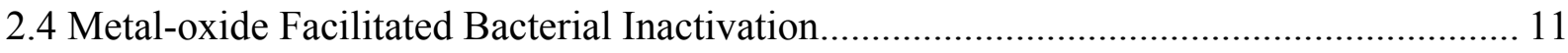


2.5 Bacterial Inactivation Kinetics

Chapter 3: Results and Discussions .

3.1 Nanomaterial Light Absorption Characteristics .................................................... 13

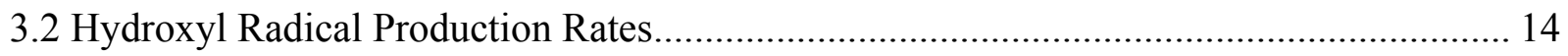

3.3 Superoxide Ion Production Rates................................................................................ 18

3.4 Nanomaterial Concentration and ROS Production .................................................... 22

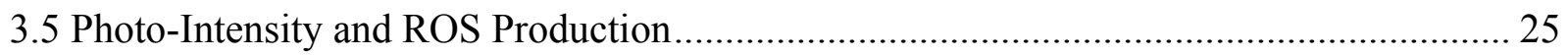

3.6 Bacterial Inactivation and ROS production rate ..................................................... 28

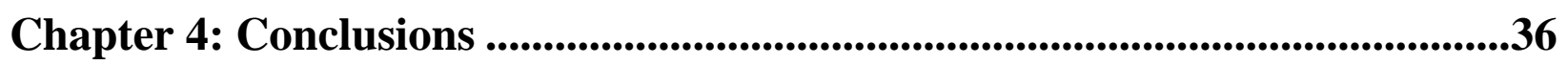

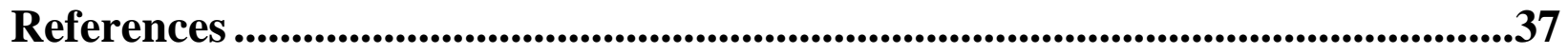




\section{List of Figures}

Figure 1. Diffuse reflectance UV-visible spectra of the five nanomaterials.

Figure 2. HPF oxidation product concentration profiles over exposure time. Experimental condition: light intensity $=1.90 \mathrm{~mW} \mathrm{~cm}^{-2}$, nanomaterial concentration $=1.0 \mathrm{~g} \mathrm{~L}^{-1}$. 15

Figure 3. Hydroxyl radical production rate per unit surface area of the five nanomaterials under two experimental conditions (light intensity $=1.12 \mathrm{~mW} \mathrm{~cm}^{-2}$ and $3.38 \mathrm{~mW} \mathrm{~cm}^{-2}$, nanomaterial concentration $=1.0 \mathrm{~g} \mathrm{~L}^{-1}$.

Figure 4. NBD-Cl reaction product concentration profiles over exposure time. Experimental condition: light intensity $=1.90 \mathrm{~mW} \mathrm{~cm}^{-2}$, nanomaterial concentration $=1.0 \mathrm{~g} \mathrm{~L}^{-1}$.

Figure 5. Superoxide ion production rate per unit surface area of the five nanomaterials under two experimental conditions (light intensity $=1.12 \mathrm{~mW} \mathrm{~cm}^{-2}$ and $1.90 \mathrm{~mW} \mathrm{~cm}^{-2}$, nanomaterial concentration $=1.0 \mathrm{~g} \mathrm{~L}^{-1}$

Figure 6(a). Hydroxyl radical production rate with $1 \mathrm{~g} \mathrm{~L}^{-1}$ nanomaterials as a function of their $\mathrm{OH}$ production rates with $0.5 \mathrm{~g} \mathrm{~L}^{-1}$

Figure 7(a). Hydroxyl radical production rate of the five nanomaterials under light intensities 3.38 and $1.90 \mathrm{~mW} \mathrm{~cm}^{-2}$ as a function of their rates under $1.12 \mathrm{~mW} \mathrm{~cm}^{-2}$. Slopes of the reference lines indicate the ratios of the light intensities (i.e., $1.90 \mathrm{~mW} \mathrm{~cm}^{-2}: 1.12 \mathrm{~mW} \mathrm{~cm}^{-2}$ and $3.38 \mathrm{~mW}$ $\mathrm{cm}^{-2}: 1.12 \mathrm{~mW} \mathrm{~cm}^{-2}$ ). The solid symbols are for the intensity ratio of $3: 1$ and open symbols are for $1.7: 1$

Figure 8. Photocatalytic log-inactivation of $E$. coli by the five nanomaterials $\left(1 \mathrm{~g} \mathrm{~L}^{-1}\right)$ under light intensity of $1.90 \mathrm{~mW} \mathrm{~cm}{ }^{-2}$. Each data represents the mean of independent triplicate experiments, three plates per replicate sample.

Figure 9. Photocatalytic inactivation rate constants per unit surface area of the five nanomaterials for $E$. coli estimated by the series-event kinetic model under two experimental conditions (Light

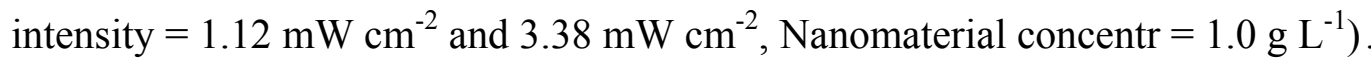


Figure 10a. Relationships between $\mathrm{OH}$ unit production rate and E. coli unit inactivation rates for the five nanomaterials under various experimental conditions ( 2 concentrations and 3 light

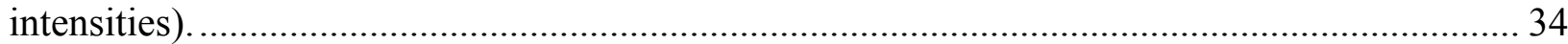




\section{List of Tables}

Table 1. Hydroxyl radical production rate per unit surface area of the five nanomaterials

Table 2. Superoxide ion production rate per unit surface area of the five nanomaterials

Table 3. Bacterial inactivation rate constants per unit surface area of the five nanomaterials for $E$. coli estimated by the series-event kinetic model 


\section{Chapter 1: Introduction}

\subsection{Emerging contaminants and research significance}

The occurrence of emerging or newly identified contaminants in our water resources is of rising concern for the human health and the environment. The current wastewater treatment systems are not designed for removing these emerging contaminants and no monitoring mechanism exists due to the absence of regulations specific to these contaminants [1].

Engineered nanomaterials are defined as materials with at least dimension less than one hundred nanometers in size. They can be spherical, tubular, or irregularly shaped, and exist as fused, aggregated or agglomerated forms of organic, inorganic, crystalline, or amorphous structures. They are produced in a variety of industries and their product inventory exceeds one thousand consumer products from three hundred companies in over twenty countries [2]. With the accelerating applications of engineered nanomaterials in commercial products and their potential uses in water treatment processes, it is inevitable that these materials are introduced into our recreational and drinking waters. Exposure to these engineered materials may create potential health or environmental risk [3].

\subsection{Nanomaterials}

Titanium dioxide is one of the top fifty chemicals produced worldwide in recent years [4]. Since its commercial production in the early twentieth century, titanium dioxide has been widely used as a pigment in sunscreens, paints, ointments, and toothpaste. Among different nanomaterials, it is the most studied $[5,6,7]$. 


\subsubsection{Titanium dioxide chemistry}

Metal oxides are common photocatalysts, of which $\mathrm{TiO}_{2}$ is the most widely used material due to its superior characteristics. With energy provided larger than its band gap, the electron/hole pairs are generated on the surface and react with $\mathrm{O}_{2}$ and $\mathrm{H}_{2} \mathrm{O}$ to form highly reactive oxidants such as hydroxyl radical $(\cdot \mathrm{OH})$, superoxide ion $\left(\mathrm{O}_{2}^{\bullet-}\right)$, and hydrogen peroxide $\left(\mathrm{H}_{2} \mathrm{O}_{2}\right)$. These strong oxidizers are collectively termed reactive oxygen species (ROS).

In general, the photochemical reaction involving $\mathrm{TiO}_{2}$ can be explained by the following series of elementary reaction steps (see equations 1 through 8 below) [8]. The first step is the light-induced $(\lambda<390 \mathrm{~nm})$ generation of a valence band hole $\left(h^{+}{ }_{v b}\right)$ and a conduction band electron ( $\left.e^{-} e b\right)$ pair (equation 1). This $e^{-}{ }_{e b}$ is available for electron donation to reducible species that are adsorbed to the $\mathrm{TiO}_{2}$ surface. It can reduce oxygen to produce the superoxide radical $\left(\mathrm{O}_{2}^{\bullet-}\right.$, equation 2) and subsequently $\mathrm{H}_{2} \mathrm{O}_{2}$ (equation 3). The superoxide ion radical can react with $\mathrm{H}_{2} \mathrm{O}_{2}$ to produce hydroxyl radical (Haber-Weiss reaction, equation 4). The reduction of $\mathrm{H}_{2} \mathrm{O}_{2}$ by $e^{-}{ }_{e b}$ can also generate hydroxyl radical (equation 5). The electron holes $\left(h^{+}{ }_{v b}\right)$ can extract electrons from absorbed oxidizable species and reacts with the surface $\mathrm{OH}^{-}$or $\mathrm{H}_{2} \mathrm{O}$ to form hydroxyl radical (equations 6 and 7). The recombination of hydroxyl radicals also produces $\mathrm{H}_{2} \mathrm{O}_{2}$ (equation 8). 


$$
\begin{gathered}
\mathrm{TiO}_{2} \stackrel{h v}{\longrightarrow} \mathrm{TiO}_{2}\left(h^{+}{ }_{v b}+e^{-}{ }_{e b}\right) \\
\mathrm{O}_{2}+e^{-}{ }_{e b} \rightarrow \mathrm{O}_{2}^{\bullet-} \\
\mathrm{O}_{2}^{\bullet-}+e^{-}{ }_{e b}+2 \mathrm{H}^{+} \rightarrow \mathrm{H}_{2} \mathrm{O}_{2} \\
\mathrm{O}_{2}^{\bullet-}+\mathrm{H}_{2} \mathrm{O}_{2} \rightarrow \bullet \mathrm{OH}+\mathrm{OH}^{-}+\mathrm{O}_{2} \\
e^{-}{ }_{e b}+\mathrm{H}_{2} \mathrm{O}_{2} \rightarrow \bullet \mathrm{OH}+\mathrm{OH}^{-} \\
h^{+}{ }_{v b}+\mathrm{OH} \\
h^{+}{ }_{v b}+\mathrm{H}_{2} \mathrm{O} \rightarrow \mathrm{OH}^{+}+\bullet \mathrm{OH}^{-} \\
2 h^{+}{ }_{v b}+2 \mathrm{H}_{2} \mathrm{O} \rightarrow 2 \mathrm{H}^{+}+\mathrm{H}_{2} \mathrm{O}_{2}
\end{gathered}
$$

\subsubsection{Antimicrobial effects characterization}

Many engineered nanomaterials such as titanium dioxide have also been shown to have strong antimicrobial properties.

i. Disinfection mechanism

It is generally accepted that the antimicrobial property of metal-oxide nanomaterials is ascribed to the production of $\operatorname{ROS}[9,10]$, which are known to be the major species contributing to inactivation processes $[11,12]$. They can cause damages to cell membranes and intracellular components, or completely oxidize the cells to carbon dioxide and water [13]. Photocatalytic disinfection using metal-oxide nanomaterials has been examined to kill both Gram-negative and Gram-positive bacteria, viruses including poliovirus, hepatitis B virus, herpes simplex virus, and MS2 bacteriophage. 
There is still much debate over which process or set of processes lead to death of microorganisms exposed to photocatalytic action. Most of the research now indicates that the destruction of the cell membrane is an important process for inactivation. For cell membrane, the lipopolysaccharides (LPS) layer and the phospholipid bilayer are made up of fatty acids. The reaction of an unsaturated fatty acid with radicals in the presence of oxygen leads to the formation of a peroxyl radical, which in turn can react with other nearby lipid molecule to generate additional lipid radical. The process is propagated as these newly formed lipid radicals react with other unsaturated lipids. The chain reaction eventually results in the oxidation of biomolecules at sites considerably distant from where the initial free radical reaction occurred [14]. Maness et al. (1999) [15] assessed the production of malondialdehyde (MDA), the most widely used biomarker for lipid peroxidation, and found a steady increase in MDA associated with cell inactivation. The ultimate impacts of membrane peroxidation are changes in cell permeability and disruption of the intact membrane, both leading to the release of cell cytoplasm and loss of membrane-mediated functions, such as respiration, semipermeability, and oxidative phosphorylation reactions [16]. The intracellular constituents released from cell cytoplasm can be decomposed by radicals directly. Free nanomaterial may also access damaged cells and subsequently attack directly intracellular components, causing alteration of protein structure [17]. Jacoby et al. (1998) [18] reported the evidence of the photocatalytic decomposition process from the whole cells to carbon dioxide and water vapor [19].

ii. Mechanistic model for microbial degradation

A disinfection kinetic model is useful for characterizing the bactericidal effects of nanomaterials and for comparing the results obtained under different experimental conditions. The Chick's Model, Chick-Watson Model, Delayed Chick-Watson model, Hom model, and the 
Kinetic power law models have been applied in the photocatalytic inactivation processes [20-24]. However, the main shortcomings of these models are their empirical nature and not built on the underlying chemical and physical processes of photocatalytic disinfection. Instead, they are built on the assumption of a homogenous chemical reaction, whereas photocatalysis is a heterogeneous process whose overall kinetics varies from those of traditional chemical disinfection and homogenous reactions in general [25].

Mechanistic models such as lipid peroxidation model, microbe-catalyst interaction model, series-event model, and multi-target model are often preferred over empirical models although they are more cumbersome from a computational perspective [26, 27]. They are expected to be more robust than empirical models and are well suited for applications for photocatalytic inactivation processes. This lipid peroxidation model emphasizes the process of membrane damages due to lipid peroxidation in photocatalytic inactivation, assuming that the hydroxyl radical is the dominant oxidant in the process. The microbe-catalyst model underscores hydrodynamic interactions between the catalyst and the microorganism from a particle size perspective. Series-event model assumes that a series of discrete damage levels exist and that each level or event is a unit of damage that occurs in a stepwise manner until the organism reaches a threshold level of damage. The multi-target model is similar to the series-event model, in that it assumes that each organism contains a finite number of discrete critical targets, each of which must be attacked for full inactivation of the organism [19].

\subsection{Research Objectives and Tasks}

Characterizing and predicting bactericidal effects of engineered metal-oxide nanomaterials on living cells have drawn much attention because of their photocatalytic characteristics and 
wide range of applications [28-30]. A potential application of such materials is disinfection for inactivating pathogenic microorganisms in medical and drinking water treatments. Photocatalytic disinfection has the advantages of no disinfection-by-products and can inactivate a wide range of microorganisms including those that are chlorine- and UV-resistant [30, 31]. The interest of quantifying metal-oxide's cytotoxic effects is also due to rapid development of nanotechnologies and the concerns for their potential impacts on ecosystems and human health [32, 33]. In particular, understanding and preventing risks to the environment and human health associated with the engineered nanomaterials have been identified to be one of the urgent needs for further development of nanotechnologies [34, 35].

It is generally accepted that the antimicrobial property of metal-oxide nanomaterials is ascribed to the reactive oxygen species (ROS) produced under light irradiation. Those highly reactive oxidants such as hydroxyl radical $(\cdot \mathrm{OH})$, superoxide ion $\left(\mathrm{O}_{2}^{--}\right)$are known to be the major species contributing to disinfection processes [36, 37]. These highly reactive species can cause damages to cell membranes and intracellular components, or completely oxidize the cells to carbon dioxide and water [38]. The ROS production capability of metal oxide nanomaterials has been reported to vary with their physical and chemical properties [39-43].

Feasibility of using relationship between ROS production capability and bacterial inactivation to characterize metal-oxide nanomaterials with a range of physical and chemical properties remains unclear. In this work, five types of titanium-oxide nanomaterials with various shapes, sizes, crystal structures, and chemical composition were chosen to explore the correlations of ROS production rates with bacterial inactivation. Production rates of both $\cdot \mathrm{OH}$ and $O_{2}^{--}$were quantified using probe molecules and spectrophotometric analyses. A pure Escherichia coli culture was exposed to the five nanomaterials under a range of ultraviolet 
irradiation and its inactivation rate was used as a biological response to the bactericidal effects of the tested nanomaterials. Bacterial inactivation rate was estimated using a series-event kinetic model, and its correlations with the ROS production rates were reported. 


\section{Chapter 2: Methods and Materials}

\subsection{Titanium-Oxide Nanomaterials}

Five types of engineered titanium-oxide nanomaterials were used in this study. Degussa P25 (average particle size $21 \mathrm{~nm}$, ca. $80 \%$ anatase and 20\% rutile, BET surface area ca. $50 \pm 15 \mathrm{~m}^{2}$ $\mathrm{g}^{-1}$ ) was obtained from Evonik Degussa (Parsippany, NJ). Anatase Nanospheres (denoted as Anatase Nsp, average diameter $150 \mathrm{~nm}$, ca. 100\% anatase, BET surface area $57.7 \mathrm{~m}^{2} \mathrm{~g}^{-1}$ ) was purchased from Alfa Cesar. The other nanomaterials used in this study were manufactured using a hydrothermal procedure reported elsewhere [44]. These nanomaterials included Anatase Nanobelts (Anatase Nb, width $60-400 \mathrm{~nm}$ and thickness $10 \mathrm{~nm}$, lengths varying from several microns to $30 \mu \mathrm{m}$, ca. $100 \%$ anatase, BET surface area $\left.20.8 \mathrm{~m}^{2} \mathrm{~g}^{-1}\right), \mathrm{TiO}_{2}(\mathrm{~B})$ Nanobelts $\left(\mathrm{TiO}_{2}(\mathrm{~B})\right.$ $\mathrm{Nb}$, width $60-400 \mathrm{~nm}$ and thickness $10 \mathrm{~nm}$, length varying from several microns to $30 \mu \mathrm{m}$, BET surface area around $\left.21.0 \mathrm{~m}^{2} \mathrm{~g}^{-1}\right)$, and $\mathrm{H}_{2} \mathrm{Ti}_{3} \mathrm{O}_{7}$ Nanobelts $\left(\mathrm{H}_{2} \mathrm{Ti}_{3} \mathrm{O}_{7} \mathrm{Nb}\right.$, width $60-400 \mathrm{~nm}$ and thickness $10 \mathrm{~nm}$, length varying from several microns to $30 \mu \mathrm{m}$, BET surface area $24.2 \mathrm{~m}^{2} \mathrm{~g}^{-1}$ ).

Stock solutions of the nanomaterials $\left(10 \mathrm{~g} \mathrm{~L}^{-1}\right)$ were prepared using de-ionized water and successively diluted to a series of working solutions with different concentrations. All solutions were subjected to ultrasonication to obtain homogeneous suspension before using in the experiments. Absorption spectra of these nanomaterials were obtained using a UV-Vis spectrophotometer (Shimadzu UV-2550). 


\subsection{Hydroxyl Radical Production Rate Estimation}

Photocatalytic production rate of $\mathrm{OH}$ was estimated based on the oxidation rate of a molecular agent, 3'-p-hydroxy phenyl fluorescein (HPF, H36004, Invitrogen Inc.). This nonfluorescent molecule is highly resistant to autoxidation, and has higher selectivity for $\cdot \mathrm{OH}$ and lower reactivity with other reactive species $[45,46]$. Its oxidation product, fluorescein, exhibits bright green emission at $490 \mathrm{~nm}$ in the presence of visible light. HPF has been successfully applied to detect hydroxyl radicals produced from $\mathrm{TiO}_{2}$ photocatalytic reactions [47].

To facilitate HPF oxidation, a freshly-made HPF stock solution was mixed with a phosphate buffer solution (PBS, $\mathrm{pH}$ 7.0) in shallow quartz dishes to obtain an initial concentration of 10 $\mu \mathrm{M}$. For each nanomaterial, a predetermined amount was added to each dish to obtain concentration of 0.5 or $1 \mathrm{~g} \mathrm{~L}^{-1}$ and a total volume of $10 \mathrm{~mL}$. One of the dishes was kept nanomaterial free to serve as a control. The mixture solutions were placed on a multi-positioned magnetic stirrer and mixed for 3 hours in the dark to allow HPF equilibrium between the aqueous phase and nanomaterials. The solutions were then exposed to a black light lamp (F40T 10BLB/RS, Sankyo Denki Company Ltd) with long-UV [48] emission peaking at $362 \mathrm{~nm}$ to catalyze ROS production.

Three UVA intensities $\left(1.12,1.90\right.$, and $3.38 \mathrm{~mW} \mathrm{~cm}^{-2}$ ) measured by a calibrated UV detector (International Light, SEL005) and a radiometer (International Light IL1400A) were used. During a 20-min exposure period, sub-samples $(1 \mathrm{~mL})$ were taken at a 2-minute interval, followed by centrifugation at $1,500 \times g$. Fluorescent intensity of the supernatant samples was quantified using a fluorescence spectrophotometer (Hitachi, F-7000) with excitation and 
emission maxima at $\sim 490$ and $\sim 515 \mathrm{~nm}$, respectively. Fluorescent intensities of standard solutions with known fluorescein concentrations $(0-10 \mu \mathrm{M})$ were used to develop a calibration curve. The initial production rate $\left(\mu \mathrm{M} \mathrm{min}{ }^{-1}\right)$ of the HPF oxidation product (i.e., fluorescein) was estimated by the slope of its concentration over exposure time, and was used as a measure of $\mathrm{OH}$ production rate $\left(\mu \mathrm{M} \min ^{-1}\right)$.

\subsection{Superoxide Ion Production Rate Estimation}

Superoxide ion production rate was estimated by monitoring the reaction rate of a molecular agent, 4-chloro-7-nitrobenzo-2-oxa-1, 3-diazole (NBD-Cl, 25455, Fluka Inc.). NBD-Cl is an electrophilic reagent and has been used to identify nucleophiles such as thiol, amine, tyrosine, and glutathione (GSH), sulfenic acids [49-52]. Olojo et al [53] reported the capability of NBD-Cl to assay superoxide ion in various systems with reliable accuracy and sensitivity.

In this study, stock solution $(10 \mathrm{mM})$ of $\mathrm{NBD}-\mathrm{Cl}$ was prepared using acetonitrile as a solvent. The sample handling procedure described in the previous section for $\cdot \mathrm{OH}$ production rate estimation was used for estimating $\mathrm{O}_{2}^{\bullet-}$ production rate. Reaction product concentration was quantified by measuring absorbance at $470 \mathrm{~nm}$ using a UV-Vis spectrophotometer (Varian Inc.,

Cary 50). A specific extinction coefficient $\left(4 \times 10^{6} \mathrm{M}^{-1} \mathrm{~cm}^{-1}\right)$ of the active product was applied for converting absorbance measurements to concentrations [54]. The specificity of the reaction was confirmed by the use of superoxide dismutase (SOD). The absorbance was completely inhibited after SOD was applied in the working system [55-57]. Using NBD-Cl to measure superoxide was demonstrated in Nick Wu's group in another coming publication. 
In the present study, HPF-based fluorescence methodologies offered several advantages including high detection sensitivity with the utilization of low concentration of the probe, the stability of the probe during bioreduction, simplicity in data collection, and high spatial resolution in microscopic imaging. NBD-Cl offers a convenient and simple spectrophotometric assay to determine superoxide [58-59]. The EPR spin-trap methods of detection of hydroxyl radical and superoxide was not used in this study. Because it requires the use of high concentrations (10 $200 \mathrm{mM}$ ) of spin trap(s) that may perturb the redox balance in the biological system. In addition, the half-life of the DMPO/ $\bullet \mathrm{OH}$ adduct is approximately 15 to 20 minutes and the $\mathrm{DMPO} / \cdot \mathrm{OOH}$ adduct is not stable, thus, the signal can diminish during the course of the experiment [60, 61].

\subsection{Metal-oxide Facilitated Bacterial Inactivation}

An Escherichia coli (ATCC 23559) culture was grown and shaken (150 rpm) overnight in LB broth at $37^{\circ} \mathrm{C}$. The bacterial culture was then centrifuged at $1,500 \times g$ for $5 \mathrm{~min}$, followed by washing, and re-suspension of the bacterial pellet in $2 \mathrm{~mL}$ PBS ( $\mathrm{pH} \mathrm{7.0)}$. The bacterial population was quantified by optical density $\left(\mathrm{OD}_{560}\right)$ and diluted with the PBS to obtain an initial

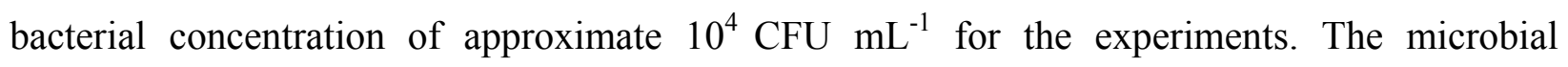
suspension was mixed with predetermined volumes of the nanomaterial working solutions in shallow quartz dishes, and then subjected to irradiation of the black light lamp. Three light intensities (i.e., 1.12, 1.90, and $3.38 \mathrm{~mW} \mathrm{~cm}^{-2}$ ) and a range of irradiation time (i.e., 0, 30, 45, 60, 75 , and $90 \mathrm{~min}$ ) were employed to examine the bactericidal effects of the nanomaterials. During the irradiation, sub-samples $(100 \mu \mathrm{L})$ were collected, diluted and spread on the LB agar plates, followed by incubation at $37{ }^{\circ} \mathrm{C}$ for $16 \mathrm{hr}$ before colony enumeration. All PBS solutions, agar materials, and quartz dishes were autoclaved at $121{ }^{\circ} \mathrm{C}$ for 20 minutes before their use. 
Log-inactivation of the E. coli was calculated and used as a biological response to the bactericidal effects of the nanomaterials.

\subsection{Bacterial Inactivation Kinetics}

Bacterial inactivation kinetics was characterized by a series event model expressed as below:

$$
\frac{N_{t}}{N_{0}}=\sum_{i=0}^{n-1} \frac{N_{i}}{N_{0}}=e^{-k^{\prime} t} \sum_{i=0}^{n-1} \frac{\left(k^{\prime} t\right)^{i}}{i !}
$$

where $N_{O}$ (cells $\mathrm{mL}^{-1}$ ) is the initial concentration of viable cells; $N_{t}\left(\right.$ cells $\left.\mathrm{mL}^{-1}\right)$ is the concentration of viable cells at time $t$; and $N_{i}\left(\right.$ cells $\left.\mathrm{mL}^{-1}\right)$ is the concentration of viable cells at event level $i(i=0-n)$. The lumped model parameters, $n$ and $k^{\prime}\left(\min ^{-1}\right)$, are the number of events that causes death of the cells and inactivation rate constant, respectively. This model has been applied to quantify the photocatalytic inactivation kinetics in previous studies [62-65]. It assumes that bacterial cells undergo a series of damaging events initiated by ROS attacks and the damages to the cells are cumulative rather than instantly lethal. Bacteria are inactivated as a consequence of the cumulative effects. Because E.coli are used as the same bacterial model for all nanomaterials. We assume $\mathrm{n}=7$, which means E.coli can be inactivated by 7 times attack. It is important to note that this model does not differentiate damages caused by different reactive oxygen species. 


\section{Chapter 3: Results and Discussions}

\subsection{Nanomaterial Light Absorption Characteristics}

The UV-visible absorption spectra (Figure 1) illustrates that the band gaps of the five nanomaterials were almost identical. Therefore, the minimum photo-energies needed for photocatalytic reactions were approximately the same for the five used nanomaterials [44].

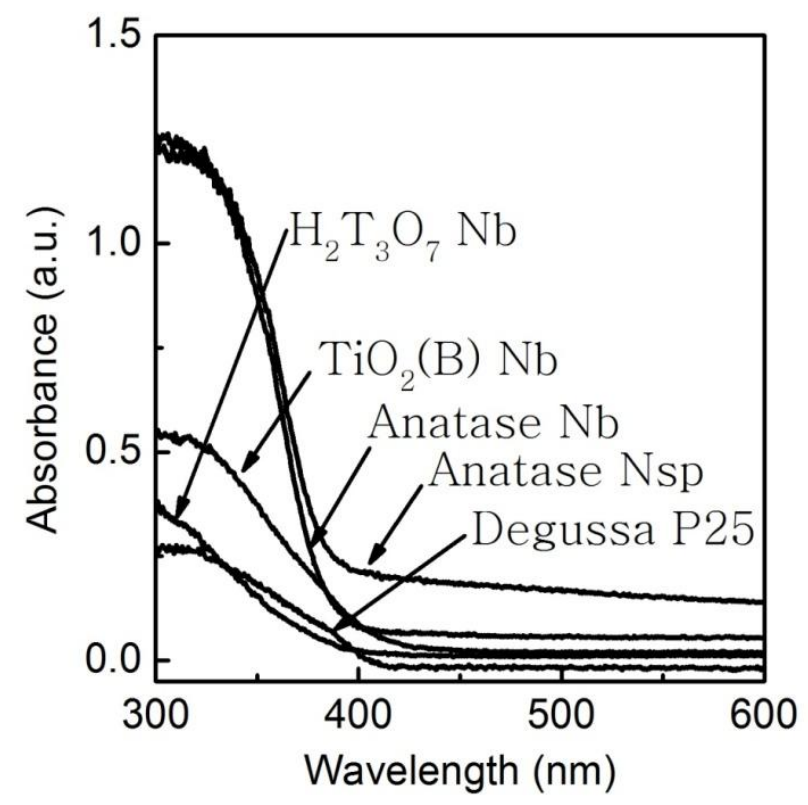

Figure 1. Diffuse reflectance UV-visible spectra of the five nanomaterials. 


\subsection{Hydroxyl Radical Production Rates}

Concentration profiles of the HPF oxidation product followed the zero-order kinetics during the initial period of the nanomaterial-UVA treatment (Figure 2). The $\mathrm{OH}$ production rates were normalized by surface area (termed as unit production rate) for comparisons across the five nanomaterials (Examples illustrated in Figure 3). Overall, Degussa P25 had the highest $\cdot \mathrm{OH}$ unit production rates among the five nanomaterials. Order of the unit production rates consistently followed: Degussa $\mathrm{P} 25>$ Anatase $\mathrm{Nb}>\mathrm{H}_{2} \mathrm{Ti}_{3} \mathrm{O}_{7} \mathrm{Nb} \approx \mathrm{TiO}_{2}(\mathrm{~B}) \mathrm{Nb} \approx$ Anatase Nsp under all experimental conditions (Table 1).

Overall, the differences in the $\mathrm{OH}$ unit production rate of the five nanomaterials were attributed to the varying phase composition, size, shape, crystal structure, and chemical composition $[66,67]$. The high production rates of Degussa P25 can partially be attributed to its mixed phase structure. Interfacial electron transferring from anatase phase to rutile phase was reported to give better charge-separation efficiency and produce more $\cdot \mathrm{OH}$ than the pure phases $[68,69]$.

Anatase $\mathrm{Nb}$ had higher $\cdot \mathrm{OH}$ unit production rates than those of $\mathrm{TiO}_{2}(\mathrm{~B}) \mathrm{Nb}$ and $\mathrm{H}_{2} \mathrm{Ti}_{3} \mathrm{O}_{7}$ $\mathrm{Nb}$. This can be attributed to a higher calcination temperature for anatase formation $\left(\sim 700{ }^{\circ} \mathrm{C}\right)$ than that for $\mathrm{TiO}_{2}(\mathrm{~B}) \mathrm{Nb}\left(\sim 400{ }^{\circ} \mathrm{C}\right)$. Higher temperature can promote crystallinity, which was reported to result in a lower recombination rate of charge carriers $[44,70,71]$. 


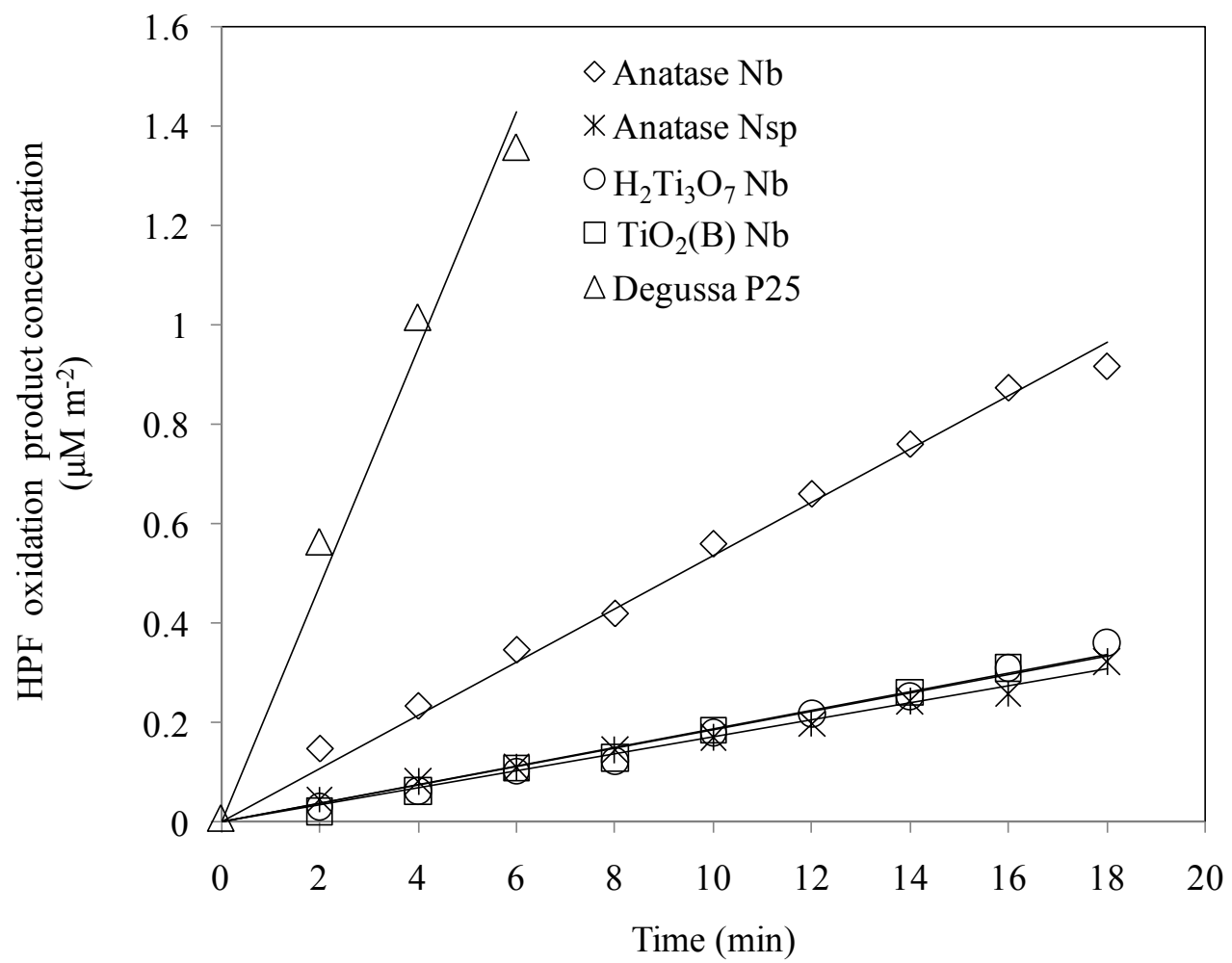

Figure 2. HPF oxidation product concentration profiles over exposure time. Experimental condition: light intensity $=1.90 \mathrm{~mW} \mathrm{~cm}^{-2}$, nanomaterial concentration $=1.0 \mathrm{~g} \mathrm{~L}^{-1}$. 


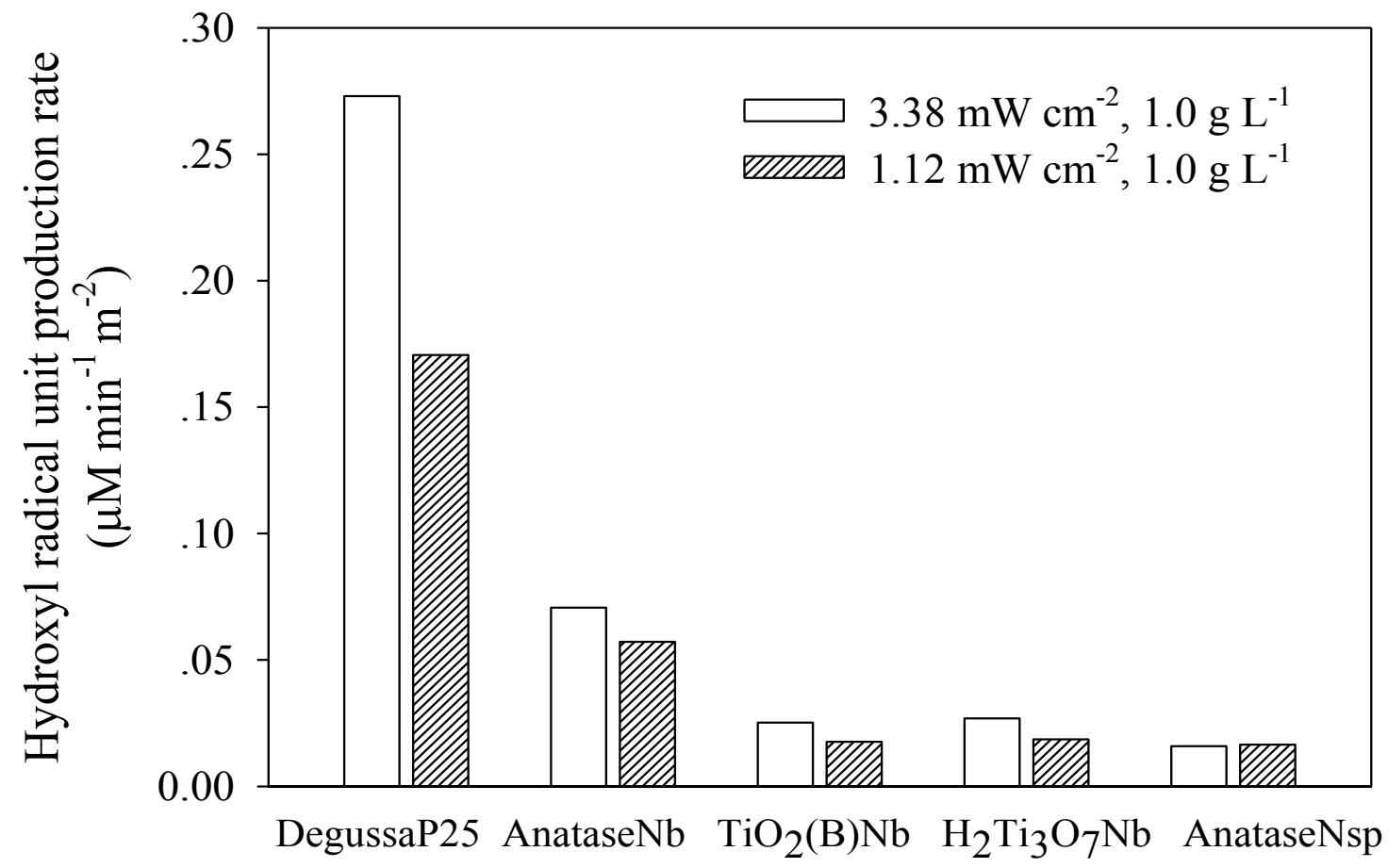

Figure 3. Hydroxyl radical production rate per unit surface area of the five nanomaterials under two experimental conditions (light intensity $=1.12 \mathrm{~mW} \mathrm{~cm}^{-2}$ and $3.38 \mathrm{~mW} \mathrm{~cm}^{-2}$, nanomaterial concentration $=1.0 \mathrm{~g} \mathrm{~L}^{-1}$. 
Table 1. Hydroxyl radical production rate per unit surface area of the five nanomaterials

\begin{tabular}{cccccc}
\hline $\begin{array}{c}\text { Experiment } \\
\text { conditions }\end{array}$ & $\begin{array}{c}\text { Degussa P25 } \\
\mathbf{R}\left(\mu \mathbf{M m i n}^{-1} \mathbf{m}^{-2}\right)\end{array}$ & $\begin{array}{c}\text { Anatase Nb } \\
\mathbf{R}\left(\mu \mathbf{M m i n}^{-1} \mathbf{m}^{-2}\right)\end{array}$ & $\begin{array}{c}\text { Anatase Nsp } \\
\mathbf{R}\left(\mu \mathbf{M m i n}^{-1} \mathbf{m}^{-2}\right)\end{array}$ & $\begin{array}{c}\mathbf{H}_{2} \mathbf{T i}_{3} \mathbf{O}_{7} \mathbf{N b} \\
\mathbf{R}\left(\mu \mathbf{M m i n}^{-1} \mathbf{m}^{-2}\right)\end{array}$ & $\begin{array}{c}\mathbf{T i O} \mathbf{O}_{2}(\mathbf{B}) \mathbf{N b} \\
\mathbf{R}\left(\mu \mathbf{M m i n}^{-1} \mathbf{m}^{-2}\right)\end{array}$ \\
\hline $1.12 \mathrm{~mW} \mathrm{~cm}^{-2}\left(0.5 \mathrm{gL}^{-1}\right)$ & 0.2644 & 0.0519 & 0.0087 & 0.0083 & 0.0124 \\
$1.12 \mathrm{~mW} \mathrm{~cm}^{-2}\left(1.0 \mathrm{gL}^{-1}\right)$ & 0.1706 & 0.0572 & 0.0165 & 0.0186 & 0.0176 \\
$1.90 \mathrm{~mW} \mathrm{~cm}^{-2}\left(0.5 \mathrm{gL}^{-1}\right)$ & 0.3804 & 0.0913 & 0.0229 & 0.0215 & 0.0314 \\
$1.90 \mathrm{~mW} \mathrm{~cm}^{-2}\left(1.0 \mathrm{gL}^{-1}\right)$ & 0.2208 & 0.0572 & 0.0146 & 0.0161 & 0.0171 \\
$3.38 \mathrm{~mW} \mathrm{~cm}^{-2}\left(0.5 \mathrm{gL}^{-1}\right)$ & 0.5208 & 0.1000 & 0.0211 & 0.0281 & 0.0314 \\
$3.38 \mathrm{~mW} \mathrm{~cm}^{-2}\left(1.0 \mathrm{gL}^{-1}\right)$ & 0.2730 & 0.0707 & 0.0159 & 0.0269 & 0.0252 \\
\hline
\end{tabular}


Data for experimental conditions under nanomaterial concentration of $1 \mathrm{~g} \mathrm{~L}^{-1}$ and three UVA intensities were repeated at least two times to confirm the reproducibility for five nanomaterials (Standard deviation $<0.004)$.

In addition, anatase was shown to be more active in adsorbing water and hydroxyl groups, which could more effectively react with electron holes on the catalyst surface and produce more hydroxyl radicals $[72,73]$. Between the two anatase materials, Anatase $\mathrm{Nb}$ had higher $\cdot \mathrm{OH}$ unit production rates than Anatase Nsp, which can be attributed to the lower electron-hole recombination rate of the nanobelt structure [44]. $\mathrm{H}_{2} \mathrm{Ti}_{3} \mathrm{O}_{7} \mathrm{Nb}$ had a different chemical composition from the other four nanomaterials, and exhibited relatively low production rates [69].

\subsection{Superoxide Ion Production Rates}

Similar to the HPF system, the concentration profiles of NBD-Cl reaction product followed the zero-order kinetics during the initial period of the nanomaterial-UVA treatment (Figure 4). Similarly, all the $O_{2}^{\bullet-}$ unit production rates were normalized by surface area for comparisons (Figure 5). The nanobelts had higher $\mathrm{O}_{2}^{--}$unit production rates than nanospheres under all the experimental conditions (Table 2). This may be attributed to the greater charge mobility in the nanobelts, which was enabled along the longitudinal dimension of the crystals [44]. It is noted that Degussa P25 had the highest $\cdot \mathrm{OH}$ unit production rates among the tested nanomaterials, but exhibited lower $\mathrm{O}_{2}^{\bullet-}$ unit production rates than the nanobelts. The higher $\mathrm{O}_{2}^{\bullet-}$ unit production rates of the nanobelts are attributed due to the exposed (101) facet of the nanobelts, which yielded an enhanced reactivity with molecular $\mathrm{O}_{2}$ and promoted the generation of $\mathrm{O}_{2}^{\circ-}$ [44]. 


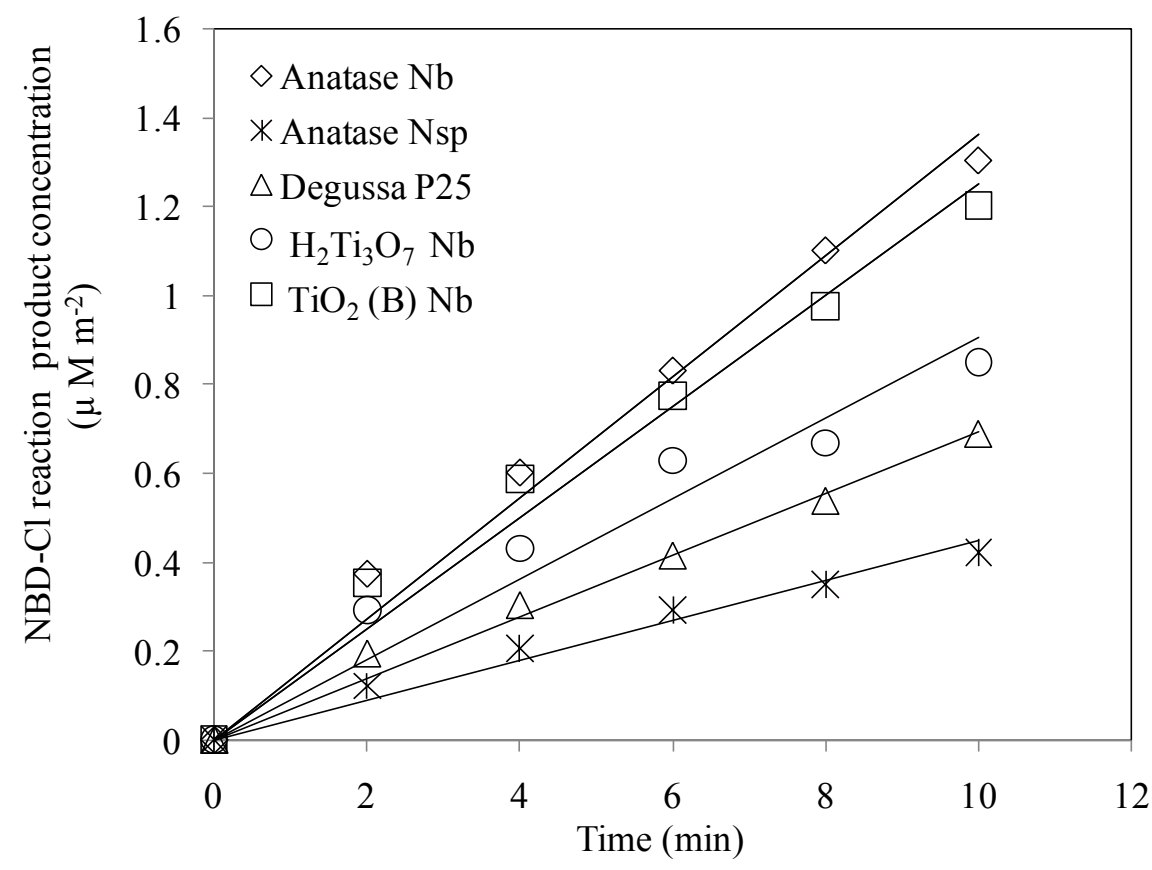

Figure 4. NBD-Cl reaction product concentration profiles over exposure time. Experimental condition: light intensity $=1.90 \mathrm{~mW} \mathrm{~cm}^{-2}$, nanomaterial concentration $=1.0 \mathrm{~g} \mathrm{~L}^{-1}$. 


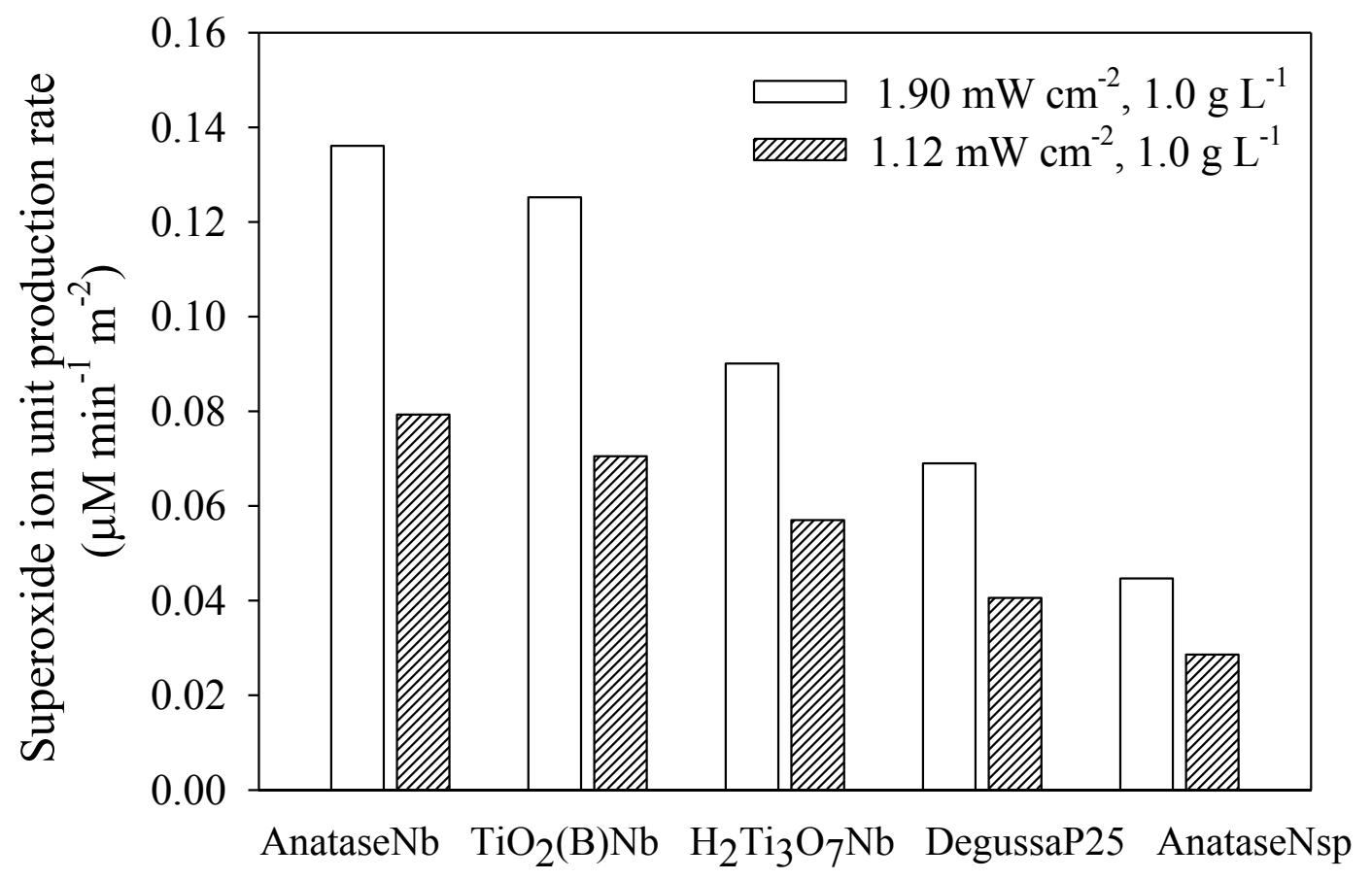

Figure 5. Superoxide ion production rate per unit surface area of the five nanomaterials under two experimental conditions (light intensity $=1.12 \mathrm{~mW} \mathrm{~cm}^{-2}$ and $1.90 \mathrm{~mW} \mathrm{~cm}^{-2}$, nanomaterial concentration $=1.0 \mathrm{~g} \mathrm{~L}^{-1}$. 
Table 2. Superoxide ion production rate per unit surface area of the five nanomaterials

\begin{tabular}{cccccc}
\hline $\begin{array}{c}\text { Experiment } \\
\text { conditions }\end{array}$ & $\begin{array}{c}\text { Degussa P25 } \\
\mathbf{R}\left(\mu \mathbf{M m i n}^{-1} \mathbf{m}^{-2}\right)\end{array}$ & $\begin{array}{c}\text { Anatase Nb } \\
\mathbf{R}\left(\mu \mathbf{M m i n}^{-1} \mathbf{m}^{-2}\right)\end{array}$ & $\begin{array}{c}\text { Anatase Nsp } \\
\mathbf{R}\left(\mu \mathbf{M m i n}^{-1} \mathbf{m}^{-2}\right)\end{array}$ & $\begin{array}{c}\mathbf{H}_{2} \mathbf{T i}_{3} \mathbf{O}_{7} \mathbf{~ N b} \\
\mathbf{R}\left(\mu \mathbf{M m i n}^{-1} \mathbf{m}^{-2}\right)\end{array}$ & $\begin{array}{c}\text { TiO } \\
\mathbf{R}(\mathbf{B}) \mathbf{N b} \\
\mathbf{R}\left(\mu \mathbf{m i n}^{-1} \mathbf{m}^{-2}\right)\end{array}$ \\
\hline $1.12 \mathrm{~mW} \mathrm{~cm}^{-2}\left(0.5 \mathrm{gL}^{-1}\right)$ & 0.1264 & 0.1769 & 0.0808 & 0.2198 & 0.2352 \\
$1.12 \mathrm{~mW} \mathrm{~cm}^{-2}\left(1.0 \mathrm{gL}^{-1}\right)$ & 0.0406 & 0.0793 & 0.0286 & 0.0570 & 0.0705 \\
$1.90 \mathrm{~mW} \mathrm{~cm}^{-2}\left(0.5 \mathrm{gL}^{-1}\right)$ & 0.1660 & 0.3106 & 0.1251 & 0.3140 & 0.2352 \\
$1.90 \mathrm{~mW} \mathrm{~cm}^{-2}\left(1.0 \mathrm{gL}^{-1}\right)$ & 0.0690 & 0.1361 & 0.0447 & 0.0901 & 0.1252 \\
$3.38 \mathrm{~mW} \mathrm{~cm}^{-2}\left(0.5 \mathrm{gL}^{-1}\right)$ & 0.2200 & 0.4356 & 0.1352 & 0.3165 & 0.3867 \\
$3.38 \mathrm{~mW} \mathrm{~cm}^{-2}\left(1.0 \mathrm{gL}^{-1}\right)$ & 0.1040 & 0.1563 & 0.0473 & 0.1364 & 0.1738 \\
\hline
\end{tabular}


Data for experimental conditions under nanomaterial concentration of $1 \mathrm{~g} \mathrm{~L}^{-1}$ over 3.38 $\mathrm{mW} \mathrm{cm}{ }^{-2}$ were repeated three times to confirm the reproducibility for five nanomaterials (Standard deviation $<0.01)$.

\subsection{Nanomaterial Concentration and ROS Production}

To examine the effects of nanomaterial concentration on ROS production, ROS production rates with nanomaterial loading $1 \mathrm{~g} \mathrm{~L}^{-1}$ were plotted as a function of those with loading $0.5 \mathrm{~g} \mathrm{~L}^{-1}$ (Figure 6a). All nanomaterials exhibited a higher $\cdot \mathrm{OH}$ production rate with $1 \mathrm{~g}^{-1}$ than its corresponding rate with $0.5 \mathrm{~g} \mathrm{~L}^{-1}$. Most of the data points in Figure 1a fell below the 2:1 reference line, indicating less efficient utilization of photo-energy with concentration $1 \mathrm{~g} \mathrm{~L}^{-1}$ than those with $0.5 \mathrm{~g} \mathrm{~L}^{-1}$. This is attributed to elevated light scattering and particle shielding and reflection with the larger nanomaerial loading $[64,74]$. Data points for the four nanomaterials other than Degussa P25 under the lowest intensity (i.e., $1.12 \mathrm{~mW} \mathrm{~cm}^{-2}$ ) fell above the 2:1 line, showing relatively better quantum yields of $\cdot \mathrm{OH}$ with $1 \mathrm{~g} \mathrm{~L}^{-1}$. These results showed that nanomaterial concentration had varying effects on their utilization of photo-energy for $\cdot \mathrm{OH}$ production.

For $\mathrm{O}_{2}^{--}$production, all the data points fell under the reference line 2:1 (Figure 6b), indicating

lower quantum yields of $\mathrm{O}_{2}^{\bullet-}$ production rates with $1 \mathrm{~g} \mathrm{~L}^{-1}$ nanomaterials. In addition, all the data points followed a fairly consistent trend, indicating the effects of nanomaterial concentration on $\mathrm{O}_{2}^{\bullet-}$ production did not vary significantly among the different nanomaterials. 


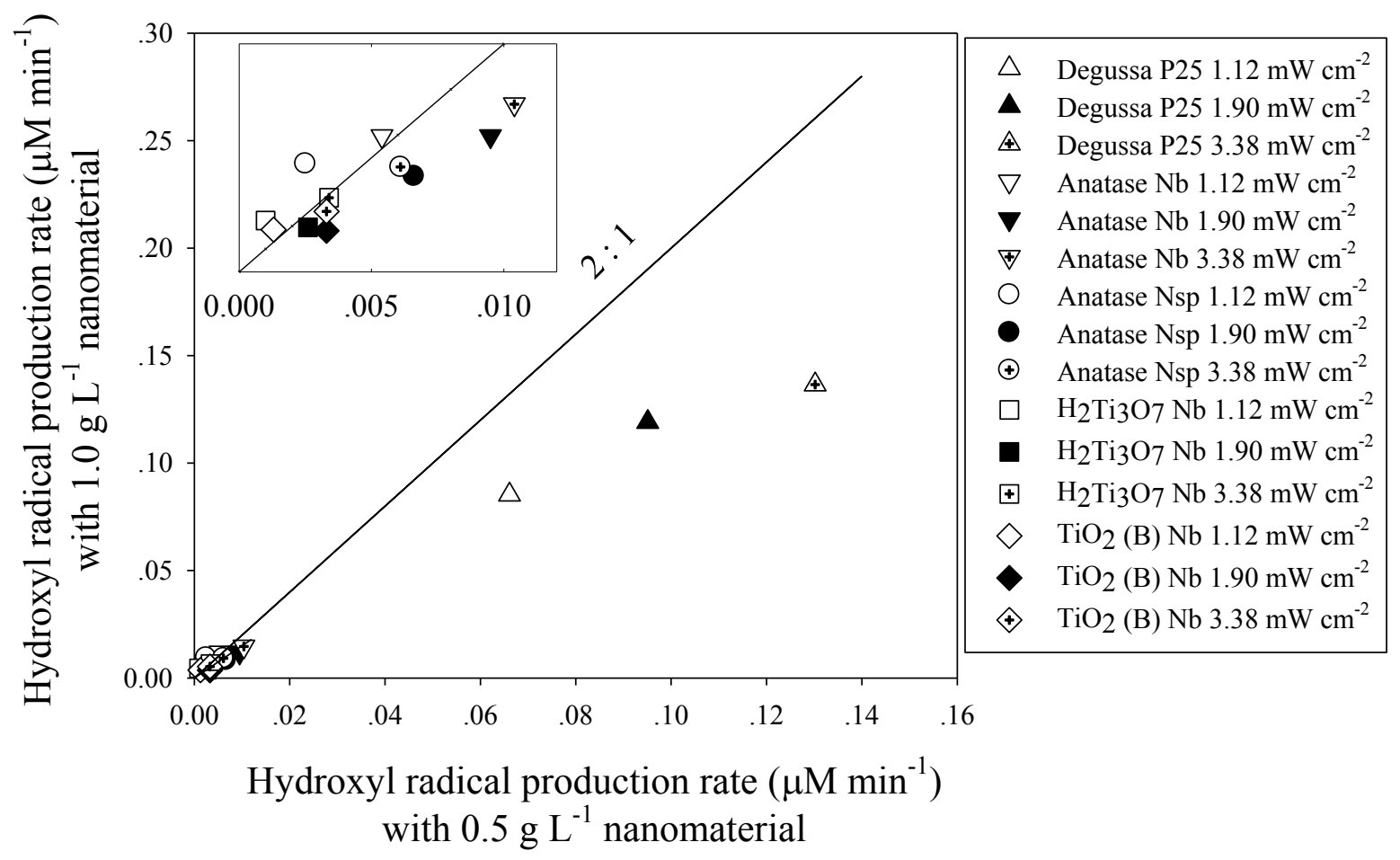

Figure 6(a). Hydroxyl radical production rate with $1 \mathrm{~g} \mathrm{~L}^{-1}$ nanomaterials as a function of their $\mathrm{OH}$ production rates with $0.5 \mathrm{~g} \mathrm{~L}^{-1}$. 


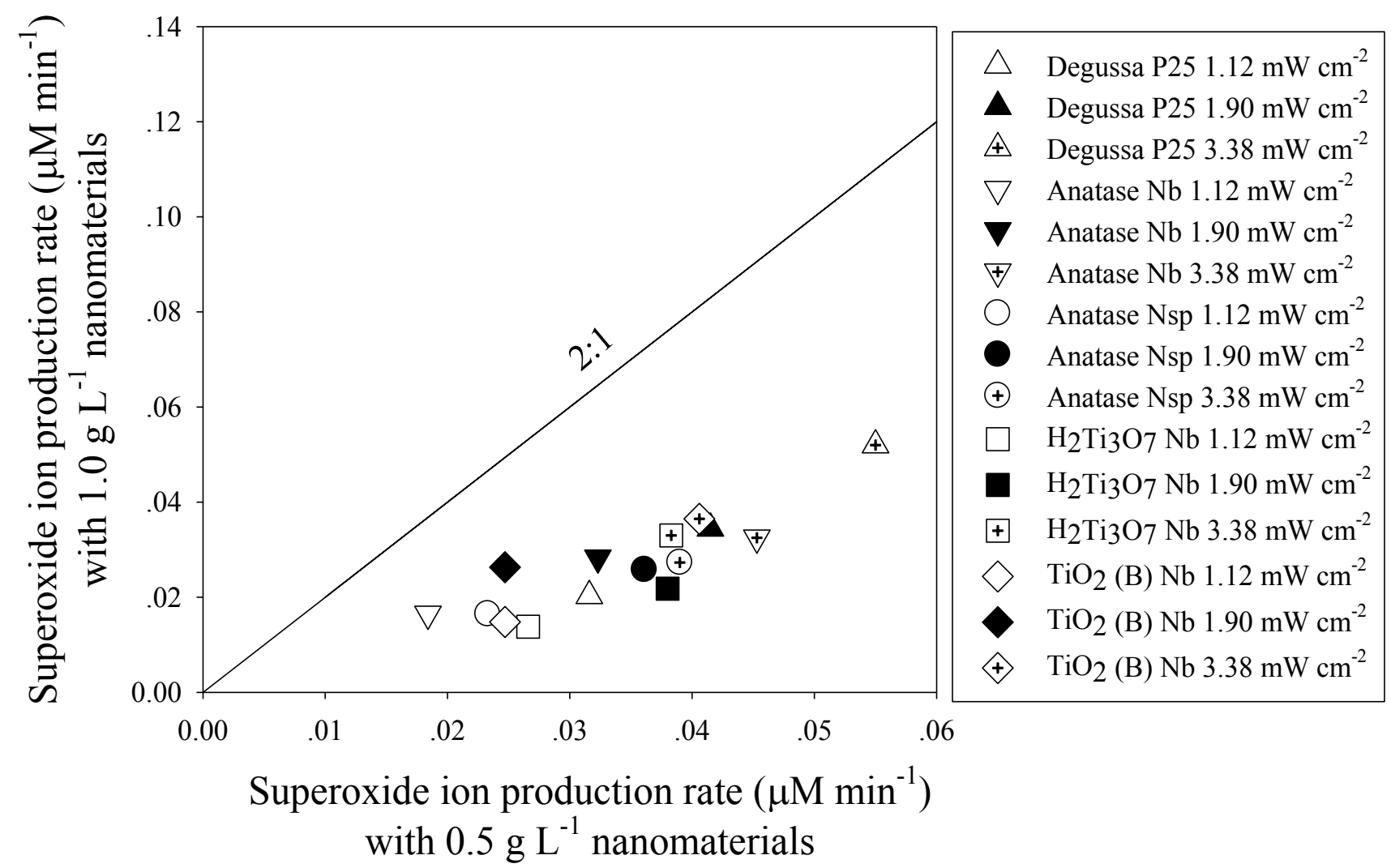

Figure 6(b). Superoxide ion production rate with $1 \mathrm{~g} \mathrm{~L}^{-1}$ nanomaterials as a function of their $\mathrm{O}_{2}^{--}$ generation rates with $0.5 \mathrm{~g} \mathrm{~L}^{-1}$ nanomaterials. 


\subsection{Photo-Intensity and ROS Production}

The ROS production rates under $3.38 \mathrm{~mW} \mathrm{~cm}^{-2}$ and $1.90 \mathrm{~mW} \mathrm{~cm}^{-2}$ were plotted as a function of those under $1.12 \mathrm{~mW} \mathrm{~cm}^{-2}$ to examine the light intensity effects (Figure 7). For $\cdot \mathrm{OH}$ production (Figure 7a), all the data points of solid symbols (i.e., production rate under $3.38 \mathrm{~mW}$ $\mathrm{cm}^{-2}$ vs. those under $1.12 \mathrm{~mW} \mathrm{~cm}^{-2}$ ) fell under the reference line $3: 1$, indicating that the nanomateials were less efficient in utilizing photo-energy for $\cdot \mathrm{OH}$ production under the higher photo-intensity. This disparity was more significant at larger nanomaterial loading $1 \mathrm{~g} \mathrm{~L}^{-1}$. Most of the data points of open symbols (i.e., production rates under $1.90 \mathrm{~mW} \mathrm{~cm}^{-2}$ vs. those under $1.12 \mathrm{~mW} \mathrm{~cm}^{-2}$ ) fell under the 1.7:1 line. The four data points that fell above the $1.7: 1$ reference line were for the four types of nanomaterials other than Degussa P25, which exhibited better utilization of photo-energy under $1.9 \mathrm{~mW} \mathrm{~cm}^{-2}$.

For the $\mathrm{O}_{2}^{\bullet-}$ production (Figure $7 \mathrm{~b}$ ), most of the data points fell under their perspective reference lines (i.e., slope of 3:1 or 1.7:1), showing lower quantum yields under the higher photo-intensities than those under $1.12 \mathrm{~mW} \mathrm{~cm}^{-2}$. Deviation of the data points from the reference line varied among the different nanomaterials, suggesting variation in the photo-energy utilization for $\mathrm{O}_{2}^{\bullet-}$ production. 


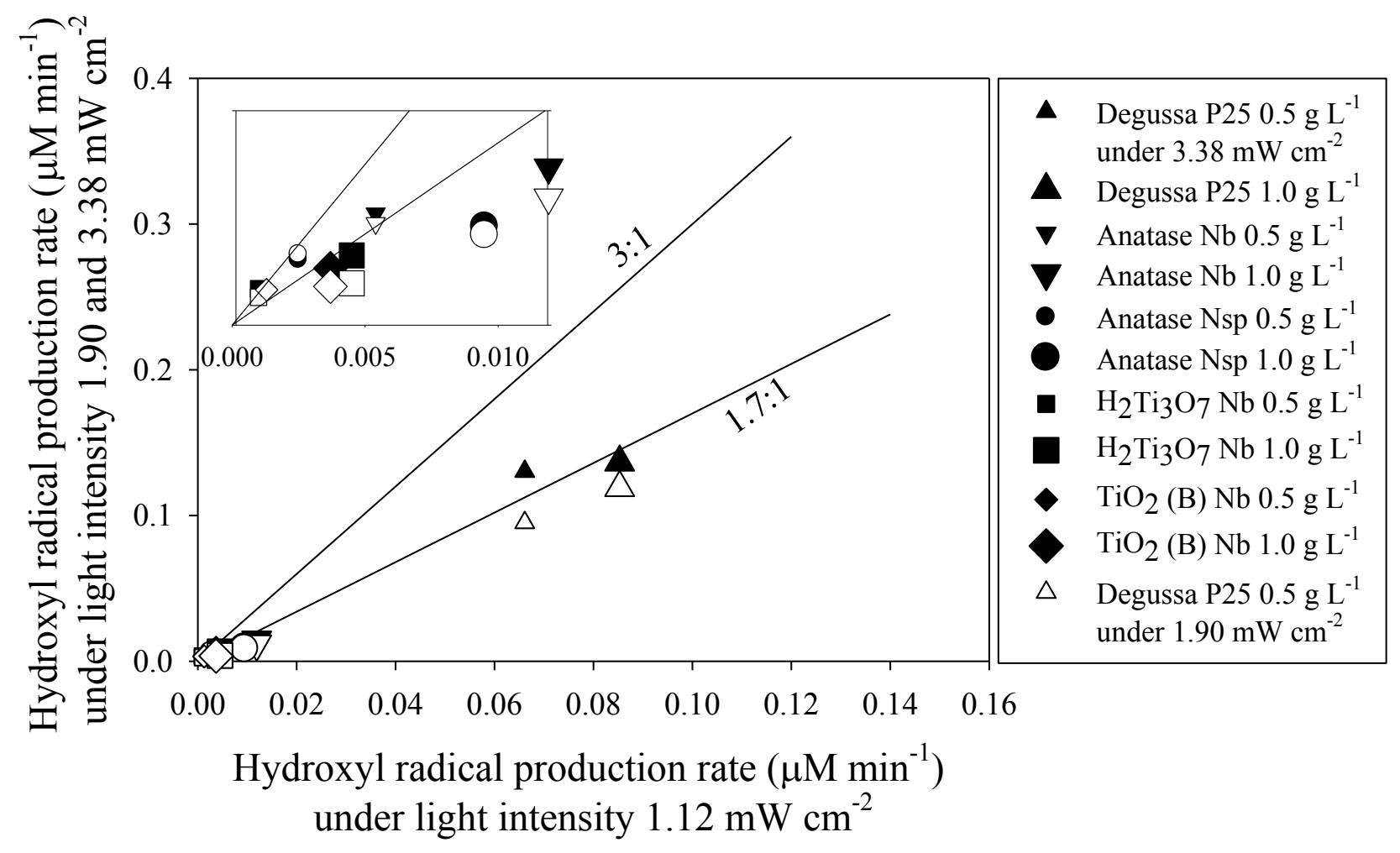

Figure 7(a). Hydroxyl radical production rate of the five nanomaterials under light intensities 3.38 and $1.90 \mathrm{~mW} \mathrm{~cm} \mathrm{~cm}^{-2}$ as a function of their rates under $1.12 \mathrm{~mW} \mathrm{~cm}^{-2}$. Slopes of the reference lines indicate the ratios of the light intensities (i.e., $1.90 \mathrm{~mW} \mathrm{~cm} \mathbf{~}^{-2}: 1.12 \mathrm{~mW} \mathrm{~cm}^{-2}$ and $3.38 \mathrm{~mW} \mathrm{~cm}^{-2}: 1.12$

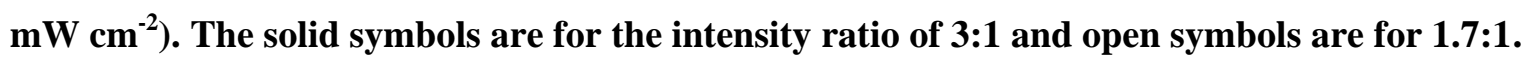




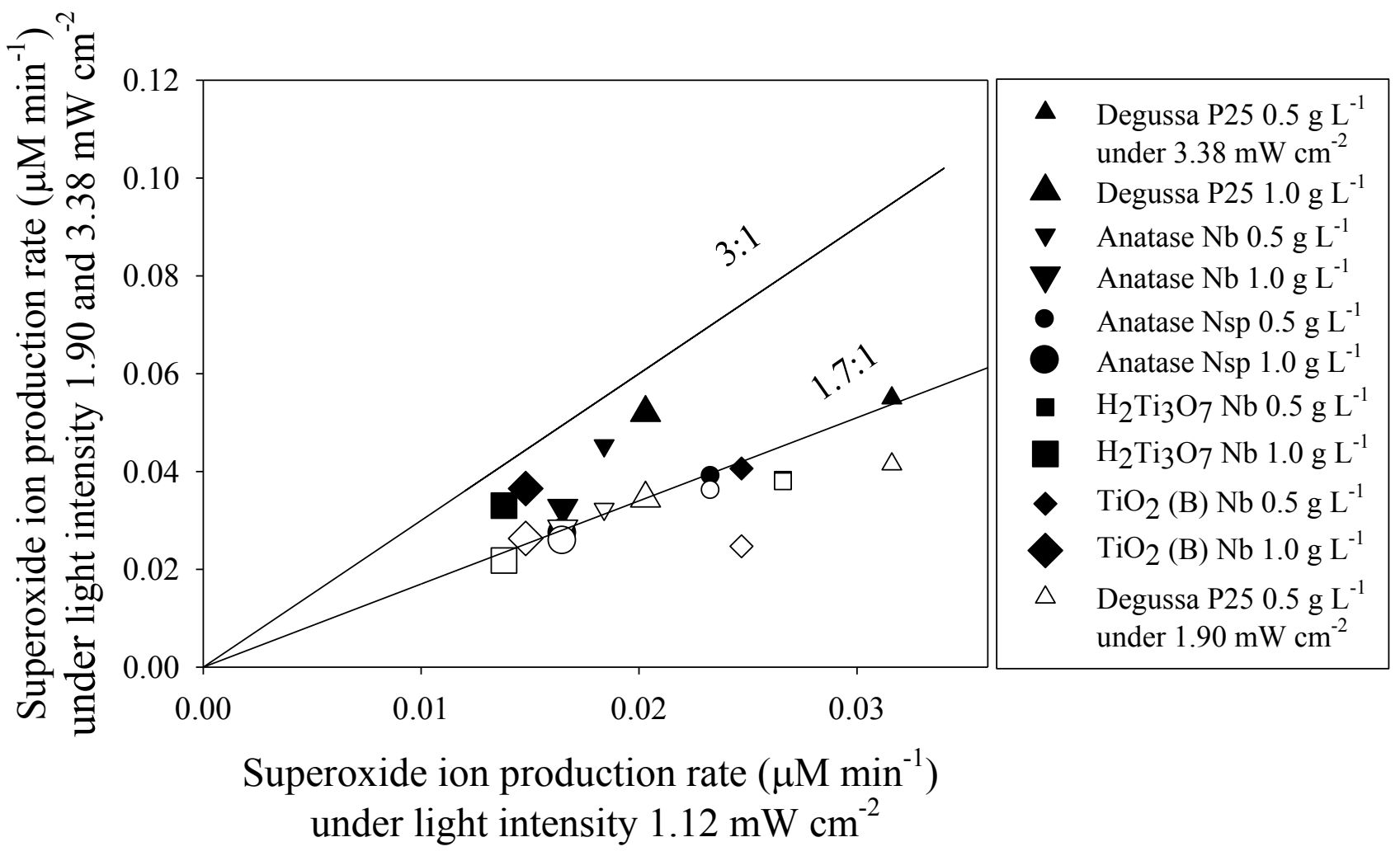

Figure 7(b). Superoxide ion production rate of the five nanomaterials under light intensity 3.38 and $1.90 \mathrm{~mW} \mathrm{~cm}^{-2}$ as a function of their rates under $1.12 \mathrm{~mW} \mathrm{~cm}^{-2}$. The lines indicate the ratios of the light intensities (i.e., $1.90 \mathrm{~mW} \mathrm{~cm}^{-2}: 1.12 \mathrm{~mW} \mathrm{~cm}^{-2}$ and $3.38 \mathrm{~mW} \mathrm{~cm}^{-2}: 1.12 \mathrm{~mW} \mathrm{~cm}^{-2}$ ). The solid symbols are for the intensity ratio of 3:1 and open symbols are for 1.7:1. 


\subsection{Bacterial Inactivation and ROS production rate}

E. coli inactivation rates estimated by the series-event model showed a consistent order among the nanomaterials under all the experimental conditions (Table 3). An example of log-inactivation as a function of exposure time is illustrated in Figure 8. It is noted that all inactivation curves for the five nanomaterials exhibited a lag followed by a declining phase in the biological response. The inactivation rate constants were normalized by surface area (termed as unit inactivation rate, examples illustrated in (Figure 9). It is noted that nanobelts exhibited higher bacterial unit inactivation rates than the nanospheres, which showed a similar pattern as the superoxide unit production rates (Figure 5).

Relationships between the unit inactivation rate and $\cdot \mathrm{OH}$ unit production rate showed varying sensitivity of the bacteria to the different nanomaterials (Figure 10a). It is noted the good correlation between the $\cdot \mathrm{OH}$ unit production rate and unit inactivation rate for Degussa P25 which was consistent with the finding of Cho et al. [36]. It is also noted that the high $\cdot \mathrm{OH}$ production rates of Degussa P25 were distinctly less efficient for bacterial inactivation than the rest nanomaterials. The distinct difference may be possibly explained by the better charge separation efficiency of Degussa P25 and relatively more production of $\cdot \mathrm{OH}$ due to its mixed phase structure $[68,69]$. One possible reason is quite part of formation of $\cdot \mathrm{OH}$ depended on $\mathrm{O}_{2}^{\bullet-}$ or $\mathrm{H}_{2} \mathrm{O}_{2}$ formed in photocatalytic reaction [75-77]. Further, when measuring total $\cdot \mathrm{OH}$ in abiotic assay, the captured $\cdot \mathrm{OH}$ can come from reactions involved with other species like $\mathrm{O}_{2}^{\bullet-}$ and $\mathrm{H}_{2} \mathrm{O}_{2}$. However, when investigating bacterial inactivation rate in biotic assay, species such as $O_{2}^{\bullet-}$ and $\mathrm{H}_{2} \mathrm{O}_{2}$ can oxidize bacteria directly without transforming into $\cdot \mathrm{OH}[78,79]$. The second possible reason was $\cdot \mathrm{OH}$ transferred into other lower oxidation species [80]. The third possible 
reason was the different contribution between $\cdot \mathrm{OH}_{\text {bulk }}$ and $\cdot \mathrm{OH}_{\text {surface. }}$. While under active debate [79], some studies reported $\cdot \mathrm{OH}_{\text {bulk }}$ was not involved in bacterial inactivation [78]. Therefore the disinfection efficiency for P25 is not higher as expected.

In contrast, a better correlation was found between the $O_{2}^{\circ-}$ unit production rate and unit inactivation rate $(r=0.87)$ (Figure 10b). Superoxide ion production depends mainly on generation of $e_{c b}^{-}$and could react immediately and be detected by the abiotic and biotic assays used in this study. Previous study reported that superoxide can work on the bacteria and organic compounds directly without transforming into other species [81]. The better correlation corroborates that $\mathrm{O}_{2}^{\bullet-}$ is one of important parameters for bacterial inactivation which is consistent with previous publications [79]. Also superoxide reactivity can be enhanced in the presence of solids like nanomaterials [82]. In this study, we did not explore the role of photogenerated hole and $\mathrm{H}_{2} \mathrm{O}_{2}$. Both of them are reported to be involved in the photocatalytic inactivation $[78,83]$. Perhaps this is part of the reason for the not perfect regression rates in Figure 3.

In present study, there rose a concern between the abiotic assay and biotic assay. The interaction pattern between the bacteria and the photocatalytic material may be different from that a chemical compound is adsorbed on the catalyst surface. But Chen et al (2009) [84] reported the good correlation of photocatalytic bactericidal effect and organic matter degradation of $\mathrm{TiO}_{2}$. However, further studies should be continued to compensate biotic measurement of reactive oxygen species.

In the literature there exists some controversy regarding which reactive oxygen species contribute more in photocatalytic inactivation. It is generally accepted that hydroxyl radicals $\cdot \mathrm{OH}$ 
are the main oxidative species responsible for the photocatalytic inactivation [85]. However, there is also some evidence that other reactive oxygen species (ROS) generated photocatalytically, such as superoxide radicals $\mathrm{O}_{2}^{--}$, hydrogen peroxide $\mathrm{H}_{2} \mathrm{O}_{2}$ also contribute to the photocatalytic inactivation. The diversity is primarily due to the different experimental conditions such as, UV/Vis irradiance [86], length exposure, photocatalyst presented in suspension or powder or films [75], range of concentration and the different photocatalysts [78, $80]$ and microorganisms employed $[87,79,88]$. There is a need for a standard condition in this area. In the present study, after comparing photocatalytic activities of metal-oxide nanomaterials with a wide range of physical and chemical properties, we suggest that using single reactive oxygen measurement (e.g., concentration or production rate) as a surrogate for predicting bactericidal effects may not be sufficient. The results provided evidence for supporting the use of a matrix of multiple ROS or biological responses for better characterizing and predicting disinfection efficiency or other cytotoxic effects. 
Table 3. Bacterial inactivation rate constants per unit surface area of the five nanomaterials for $E$. coli estimated by the series-event kinetic model

\begin{tabular}{|c|c|c|c|c|c|}
\hline $\begin{array}{l}\text { Experiment } \\
\text { Conditions }\end{array}$ & $\begin{array}{l}\text { Degussa P25 } \\
k^{\prime}\left(\min ^{-1} \mathbf{m}^{-2}\right)\end{array}$ & $\begin{array}{l}\text { Anatase } \mathrm{Nb} \\
k^{\prime}\left(\min ^{-1} \mathrm{~m}^{-2}\right)\end{array}$ & $\begin{array}{l}\text { Anatase Nsp } \\
k^{\prime}\left(\min ^{-1} \mathbf{m}^{-2}\right)\end{array}$ & $\begin{array}{l}\mathrm{H}_{2} \mathrm{Ti}_{3} \mathrm{O}_{7} \mathrm{Nb} \\
k^{\prime}\left(\min ^{-1} \mathrm{~m}^{-2}\right)\end{array}$ & $\begin{array}{c}\mathrm{TiO}_{2}(\mathrm{~B}) \mathrm{Nb} \\
k^{\prime}\left(\min ^{-1} \mathrm{~m}^{-2}\right)\end{array}$ \\
\hline $1.12 \mathrm{~mW} \mathrm{~cm}^{-2}, 0.5 \mathrm{~g} \mathrm{~L}^{-1}$ & 0.56 & 0.84 & 0.25 & 0.5 & 0.74 \\
\hline$\left(\mathrm{R}^{2}\right)$ & 0.93 & 0.92 & 0.87 & 0.83 & 0.85 \\
\hline $1.12 \mathrm{~mW} \mathrm{~cm}^{-2}, 1.0 \mathrm{~g} \mathrm{~L}^{-1}$ & 0.26 & 0.4 & 0.16 & 0.37 & 0.41 \\
\hline$\left(\mathrm{R}^{2}\right)$ & 0.82 & 0.42 & 0.73 & 0.98 & 0.99 \\
\hline $1.90 \mathrm{~mW} \mathrm{~cm}^{-2}, 0.5 \mathrm{~g} \mathrm{~L}^{-1}$ & 0.88 & 1.15 & 0.73 & 0.91 & 1.24 \\
\hline$\left(\mathrm{R}^{2}\right)$ & 0.93 & 0.84 & 0.86 & 0.61 & 0.94 \\
\hline $1.90 \mathrm{~mW} \mathrm{~cm}^{-2}, 1.0 \mathrm{~g} \mathrm{~L}^{-1}$ & 0.46 & 0.58 & 0.23 & 0.37 & 0.43 \\
\hline$\left(\mathrm{R}^{2}\right)$ & 0.96 & 0.83 & 0.97 & 0.94 & 0.9 \\
\hline $3.38 \mathrm{~mW} \mathrm{~cm}^{-2}, 0.5 \mathrm{~g} \mathrm{~L}^{-1}$ & 1.24 & 3.27 & 1.18 & 1.82 & 2.1 \\
\hline$\left(\mathrm{R}^{2}\right)$ & 0.81 & 0.96 & 0.95 & 0.88 & 0.89 \\
\hline $3.38 \mathrm{~mW} \mathrm{~cm}^{-2}, 1.0 \mathrm{~g} \mathrm{~L}^{-1}$ & 0.78 & 1.06 & 0.38 & 0.95 & 1.05 \\
\hline$\left(\mathrm{R}^{2}\right)$ & 0.92 & 0.94 & 0.89 & 0.97 & 0.87 \\
\hline
\end{tabular}




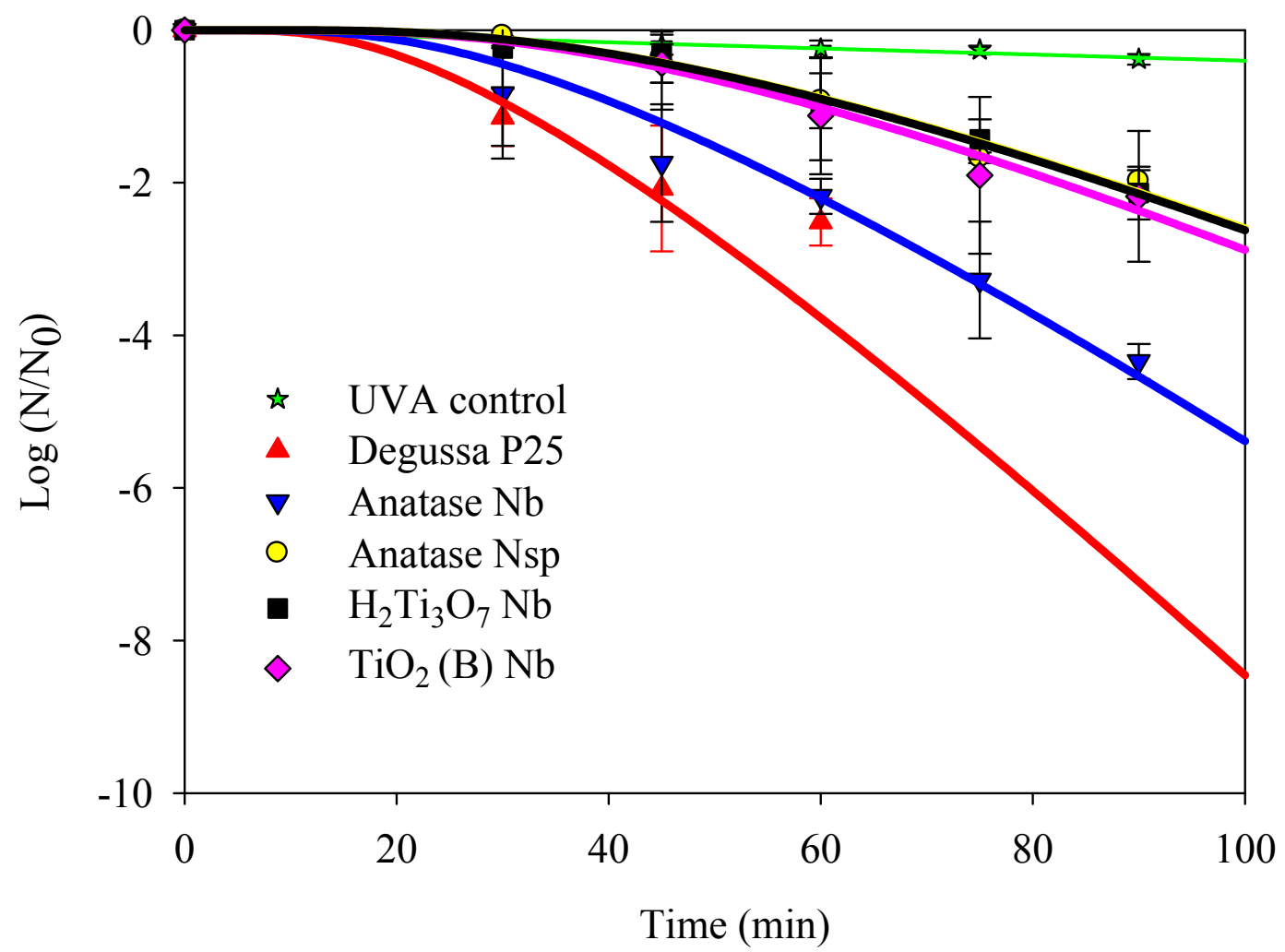

Figure 8. Photocatalytic log-inactivation of $E$. coli by the five nanomaterials $\left(1 \mathrm{~g} \mathrm{~L}^{-1}\right)$ under light intensity of $1.90 \mathrm{~mW} \mathrm{~cm}^{-2}$. Each data represents the mean of independent triplicate experiments, three plates per replicate sample. 


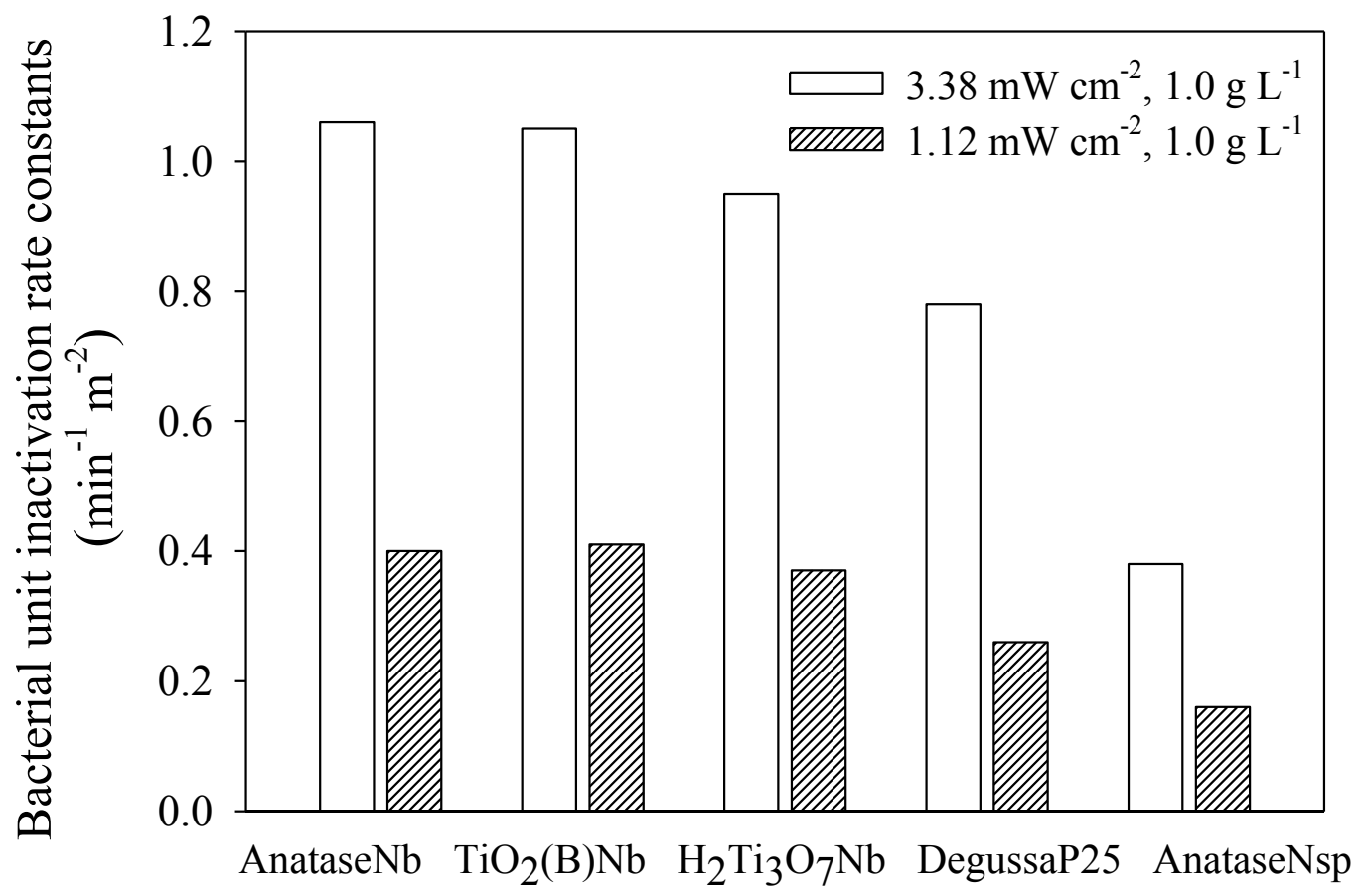

Figure 9. Photocatalytic inactivation rate constants per unit surface area of the five nanomaterials for $E$. coli estimated by the series-event kinetic model under two experimental conditions (Light intensity $=1.12 \mathrm{~mW} \mathrm{~cm}^{-2}$ and $3.38 \mathrm{~mW} \mathrm{~cm}^{-2}$, Nanomaterial concentr $=1.0 \mathrm{~g} \mathrm{~L}^{-1}$ ) 


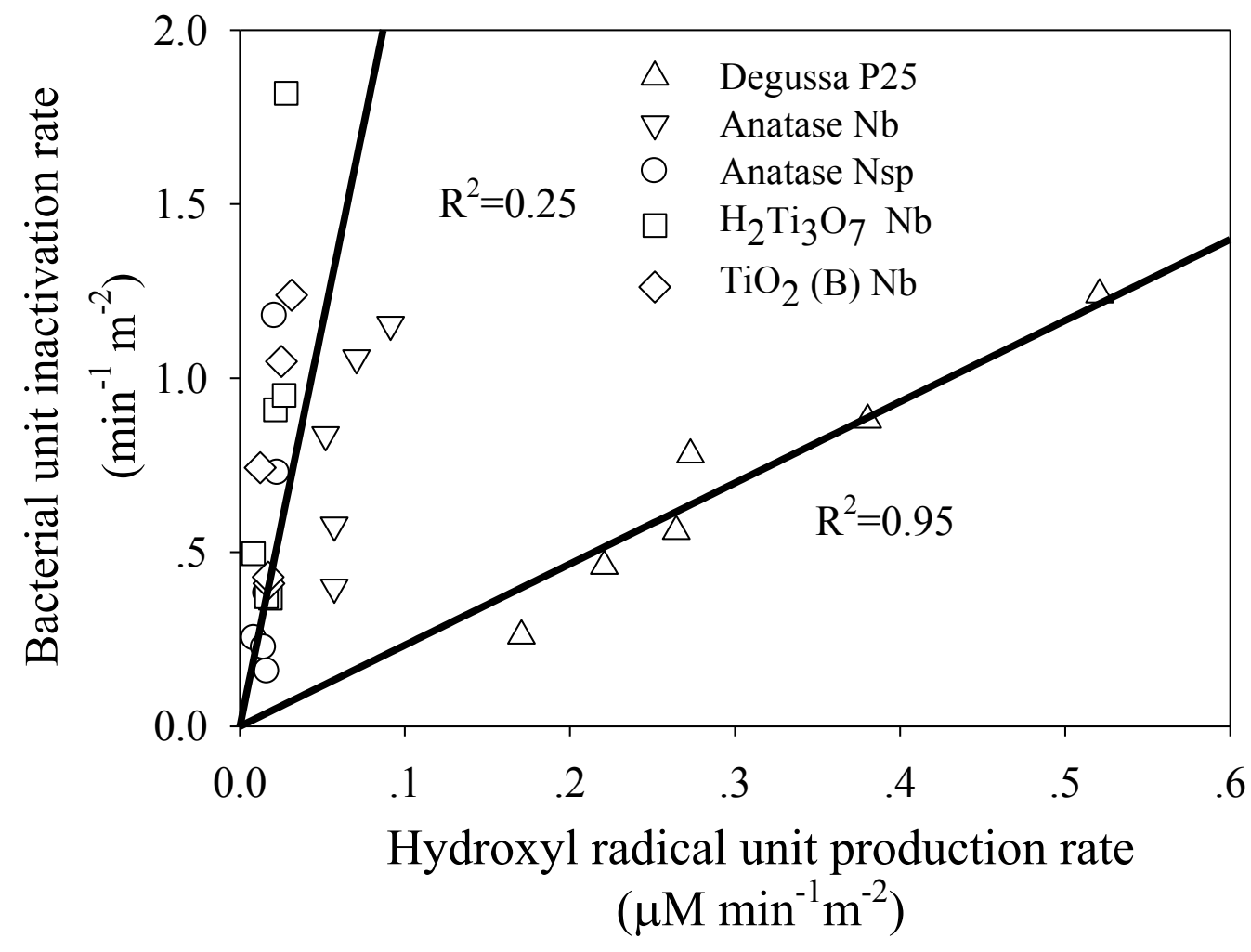

Figure 10a. Relationships between $\mathrm{OH}$ unit production rate and $E$. coli unit inactivation rates for the five nanomaterials under various experimental conditions ( 2 concentrations and 3 light intensities). 


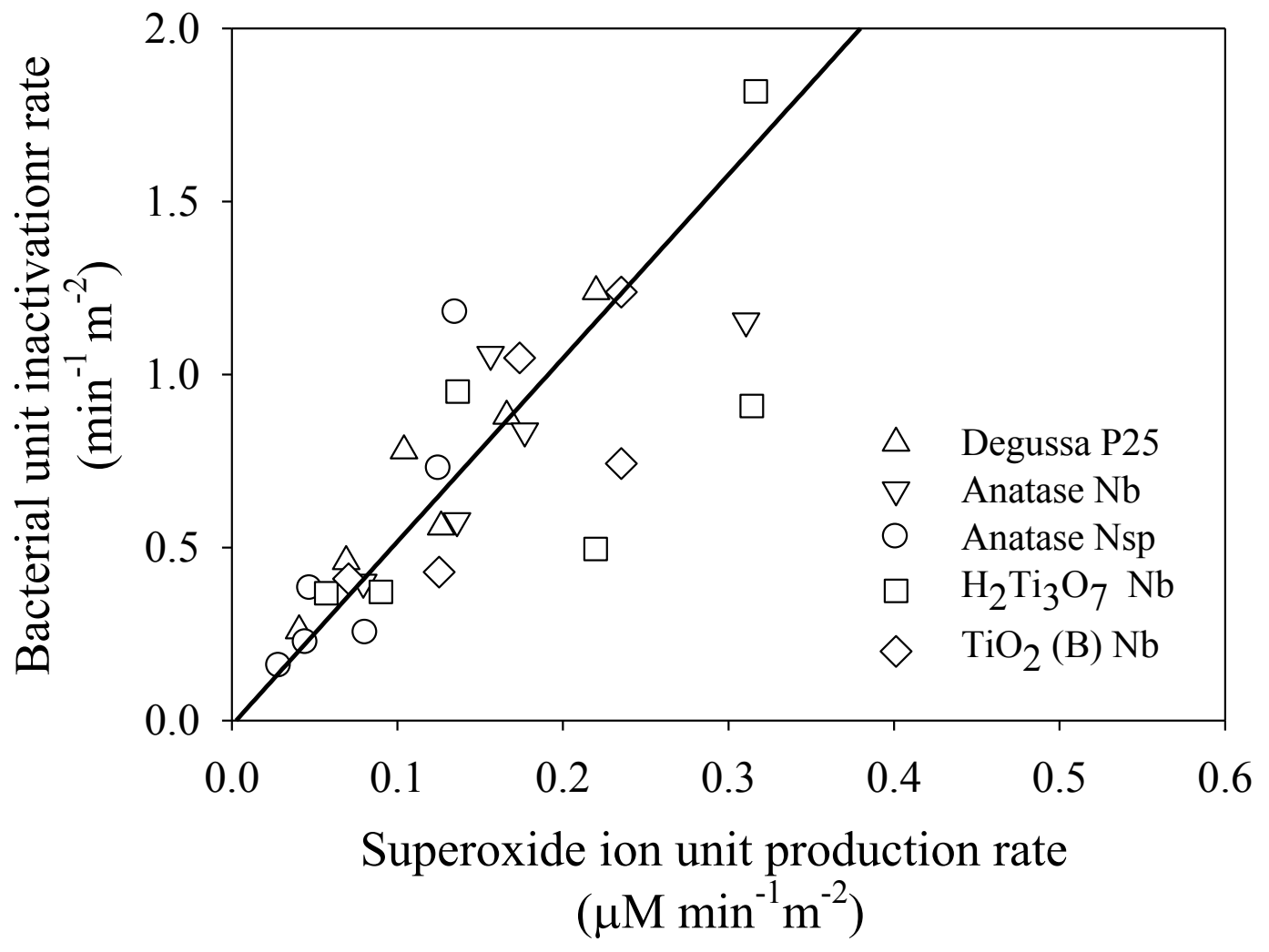

Figure 10b. Relationships between $\mathrm{O}_{2}{ }^{--}$unit production rate and $E$. coli unit inactivation rates for the five nanomaterials under various experimental conditions ( 2 concentrations and 3 light intensities) 


\section{Chapter 4: Conclusions}

1. Degussa $\mathrm{P} 25$ had the highest $\cdot \mathrm{OH}$ unit production rates among the five nanomaterials but exhibited lower $\mathrm{O}_{2}^{--}$unit production rates than the nanobelts. Nanobelts exhibited higher bacterial unit inactivation rates than the nanospheres, which showed a similar pattern as the superoxide unit production rates. Nanomaterial concentration had varying effects on their utilization of photo-energy for $\cdot \mathrm{OH}$ production. Nanomaterial concentration on $\mathrm{O}_{2}^{\bullet-}$ production did not vary significantly among the different nanomaterials. Relationships between the unit inactivation rate and $\cdot \mathrm{OH}$ unit production rate showed varying sensitivity of the bacteria to the different nanomaterials. A better correlation was found between the $O_{2}^{\bullet-}$ unit production rate and unit inactivation rate $(r=0.87)$.

2. To compare photocatalytic activities of metal-oxide nanomaterials with a wide range of physical and chemical properties, using single reactive oxygen measurement (e.g., concentration or production rate) as a surrogate for predicting bactericidal effects may not be sufficient. The thesis provided evidence for supporting the use of a matrix of multiple ROS or biological responses for better characterizing and predicting disinfection efficiency or other cytotoxic effects.

3. Future work may extend to examine the photocatalytic inactivation of other microorganisms such as virus, protozoa, fungi and algae with different irradiation intensities and nanomaterial loading. Relationship between reactive oxygen species (ROS) production and microorganism inactivation rates will be examined. A model based on examining ROS production and inactivation rates to predict the disinfection effect of photocatalysis are expected to construct. 


\section{References}

1. Bolong, N.; Ismail, A. F.; Salim, M. R.; Matsuura, T., A review of the effects of emerging contaminants in wastewater and options for their removal. Desalination 2009, 239, (1-3), 229-246.

2. Linkov, I.; Steevens, J., Nanomaterials: risks and benefits. 2008, 1-472, Springer press.

3. Weinberg, H.; Galyean, A.; Leopold, M., Evaluating engineered nanoparticles in natural waters. TrAC Trends in Analytical Chemistry 2011, 30, (1), 72-83.

4. Praff, G.; Reynders, Angle dependent optical effects deriving from submicron structures of films and pigments. Chemical Review 1999, 99, (7), 1963-1982.

5. Maynard, A. D.; Aitken, R. J.; Butz, T.; Colvin, V.; Donaldson, K.; Oberdorster, G.; Philbert, M. A.; Ryan, J.; Seaton, A.; Stone, V.; Tinkle, S. S.; Tran, L.; Walker, N. J.; Warheit, D. B., Safe handling of nanotechnology. Nature 2006, 444, (7117), 267-269.

6. Sunada, K.; Watanabe, T.; Hashimoto, K., Studies on photokilling of bacteria on $\mathrm{TiO}_{2}$ thin film. Journal of Photochemistry and Photobiology A: Chemistry 2003, 156, (1-3), 227-233.

7. Wu, N.; Wang, J.; Li, M.; Zhi, M.; Manivannan, A., Hydrothermal synthesis and photocatalytic activity of titanium dioxide nanotubes, nanowires and nanospheres. Materials Research Society 2009, 1144 .

8. Cho, M.; Chung, H.; Choi, W.; Yoon, J., Different inactivation behaviors of MS-2 phage and Escherichia coli in $\mathrm{TiO}_{2}$ photocatalytic disinfection. Applied and Environmental Microbiology. 2005, 71, (1), 270-275.

9. Chen, F.; Yang, X.; Xu, F.; Wu, Q.; Zhang, Y., Correlation of photocatalytic bactericidal effect and organic matter degradation of $\mathrm{TiO}_{2}$ Part I: observation of phenomena. Environmental Science \& Technology 2009, 43, (4), 1180-1184.

10. Wiesner, M.R; Greg V.; Alvarez, L.P.; Dionysiou, D.; Biswas, P., Assessing the risks of manufactured nanomaterials. Environmental Science \& Technology 2006, 40, (14), 4336-4345.

11. Watts, R. J.; Washington, D.; Howsawkeng, J.; Loge, F. J.; Teel, A. L., Comparative toxicity of hydrogen peroxide, hydroxyl radicals, and superoxide anion to Escherichia coli. Advances in Environmental Research 2003, 7, (4), 961-968.

12. Rincón, A.-G.; Pulgarin, C., Effect of $\mathrm{pH}$, inorganic ions, organic matter and $\mathrm{H}_{2} \mathrm{O}_{2}$ on E. coli $\mathrm{K} 12$ photocatalytic inactivation by $\mathrm{TiO}_{2}$ : Implications in solar water disinfection. Applied Catalysis $B$ : Environmental 2004, 51, (4), 283-302.

13. Chen, F.; Yang, X.; Mak, H. K. C.; Chan, D. W. T., Photocatalytic oxidation for antimicrobial control in built environment: A brief literature overview. Building and Environment 2010, 45, (8), 1747-1754.

14. Porter, N.; Caldwell, S.; Mills, K., Mechanisms of free radical oxidation of unsaturated lipids. Lipids 1995, 30, (4), 277-290.

15. Maness, P.-C.; Smolinski, S.; Blake, D. M.; Huang, Z.; Wolfrum, E. J.; Jacoby, W. A., bactericidal activity of photocatalytic $\mathrm{TiO}_{2}$ reaction: toward an understanding of its killing mechanism. Applied and Environmental Microbiology 1999, 65, (9), 4094-4098. 
16. Cheng, Y. W.; Chan, R. C. Y.; Wong, P. K., Disinfection of legionella pneumophila by photocatalytic oxidation. Water Research 2007, 41, (4), 842-852.

17. Swetha, S.; Kumari Singh, M.; Minchitha, K. U.; Geetha Balakrishna, R., Elucidation of cell killing mechanism by comparative analysis of photoreactions on different types of bacteria. Photochemistry and Photobiology 2012, 88, (2), 414-422.

18. Jacoby, W. A.; Maness, P. C.; Wolfrum, E. J.; Blake, D. M.; Fennell, J. A., Mineralization of bacterial cell mass on a photocatalytic surface in air. Environmental Science \& Technology 1998, 32 , (17), 2650-2653.

19. Dalrymple, O. K.; Stefanakos, E.; Trotz, M. A.; Goswami, D. Y., A review of the mechanisms and modeling of photocatalytic disinfection. Applied Catalysis B: Environmental 2010, 98, (1-2), 27-38.

20. Chick, H., An investigation of the laws of disinfection. The Journal of Hygiene (London) 1908, 8.

21. Watson, H. E., A Note On The variation of the rate of disinfection with change in the concentration of the disinfectant. The Journal of Hygiene (London) 1908.

22. Rennecker, J. L.; Marinas, B. J.; Owens, J. H.; Rice, E. W., Inactivation of cryptosporidium parvum oocysts with ozone. Water Research 1999, 33, (11), 2481-2488.

23. Hom, L. W., Kinetics of chlorine disinfection in an ecosystem. Journal of the Sanitary Engineering Division 1972, 98, (1).

24. Wei, C.; Lin, W. Y.; Zainal, Z.; Williams, N. E.; Zhu, K.; Kruzic, A. P.; Smith, R. L.; Rajeshwar, $\mathrm{K}$., Bactericidal activity of $\mathrm{TiO}_{2}$ photocatalyst in aqueous media: toward a solar-assisted water disinfection system. Environmental Science \& Technology 1994, 28, (5), 934-938.

25. Cho, M.; Chung, H.; Choi, W.; Yoon, J., Linear correlation between inactivation of E. coli and $\mathrm{OH}$ radical concentration in $\mathrm{TiO}_{2}$ photocatalytic disinfection. Water Research 2004, 38, (4), 1069-1077.

26. Barclay, L. R. C.; Baskin, K. A.; Kong, D.; Locke, S. J., Autoxidation of model membranes. The kinetics and mechanism of autoxidation of mixed phospholipid bilayers. Canadian Journal of Chemistry 1987, 65, (11), 2541-2550.

27. Severin, B. F.; Suidan, M. T.; Engelbrecht, R. S., Kinetic modeling of U.V. disinfection of water. Water Research 1983, 17, (11), 1669-1678.

28. McCullagh, C.; Robertson, J. M. C.; Bahnemann, D. W.; Robertson, P. K. J. The application of $\mathrm{TiO}_{2}$ photocatalysis for disinfection of water contaminated with pathogenic micro-organisms: a review. Research on Chemical Intermediates 2007, 33 (3-5), 359-375.

29. Salih, F. M. Formulation of a mathematical model to predict solar water disinfection. Water Research 2003, 37 (16), 3921-3927.

30. Prasad, G. K.; Ramacharyulu, P. V. R. K.; Merwyn, S.; Agarwal, G. S.; Srivastava, A. R.; Singh, B.; Rai, G. P.; Vijayaraghavan, R., Photocatalytic inactivation of spores of bacillus anthracis using titania nanomaterials. Journal of Hazardous Materials 2011, 185, (2-3), 977-982.

31. Lonnen, J.; Kilvington, S.; Kehoe, S. C.; Al-Touati, F.; McGuigan, K. G. Solar and photocatalytic disinfection of protozoan, fungal and bacterial microbes in drinking water. Water Research. 2005, 39 (5), 877-883.

32. Oberdorster, G.; Stone, V.; Donaldson, K. Toxicology of nanoparticles: A historical perspective. Nanotoxicology 2007, 1 (1), 2-25. 
33. Donaldson, K.; Stone, V.; Tran, C. L.; Kreyling, W.; Borm, P. J. A. Nanotoxicology. Occupational and Environmental Medicine 2004, 61 (9), 727-728.

34. Behra, R.; Krug, H. Nanoecotoxicology: Nanoparticles at large. Nature Nanotechnology 2008, 3 (5), 253-254.

35. Maynard, A. D.; Aitken, R. J.; Butz, T.; Colvin, V.; Donaldson, K.; Oberdorster, G.; Philbert, M. A.; Ryan, J.; Seaton, A.; Stone, V.; Tinkle, S. S.; Tran, L.; Walker, N. J.; Warheit, D. B. Safe handling of nanotechnology. Nature 2006, 444 (7117), 267-269.

36. Cho, M.; Chung, H.; Choi, W.; Yoon, J., Linear correlation between inactivation of E. coli and $\mathrm{OH}$ radical concentration in $\mathrm{TiO}_{2}$ photocatalytic disinfection. Water Research 2004, 38, (4), 1069-1077.

37. Maness, P. C.; Smolinski, S.; Blake, D. M.; Huang, Z.; Wolfrum, E. J.; Jacoby, W. A. bactericidal activity of photocatalytic $\mathrm{TiO}_{2}$ reaction: toward an understanding of its killing mechanism. Applied and Environmental Microbiology. 1999, 65 (9), 4094-4098.

38. Wu, P.; Xie, R.; Imlay, J. A.; Shang, J. K., Visible-light-induced photocatalytic inactivation of bacteria by composite photocatalysts of palladium oxide and nitrogen-doped titanium oxide. Applied Catalysis B: Environmental 2009, 88, (3-4), 576-581.

39. McLaren, A.; Valdes-Solis, T.; Guoqiang, L.; Shik Chi, T. Shape and size effects of ZnO nanocrystals on photocatalytic activity. Journal of American Chemical Society 2009, 131 (35), 12540-12541.

40. Liao, D. L.; Liao, B. Q. Shape, size and photocatalytic activity control of $\mathrm{TiO}_{2}$ nanoparticles with surfactants. Journal of Photochemistry and Photobiology A: chemistry 2007, 187 (2-3), 363-369.

41. Sato, T.; Taya, M. Enhancement of phage inactivation using photocatalytic titanium dioxide particles with different crystalline structures. Biochemical Engineering Journal 2006, 28 (3), 303-308.

42. Hurum, D. C.; Agrios, A. G.; Gray, K. A.; Rajh, T.; Thurnauer, M. C. Explaining the enhanced photocatalytic activity of degussa P25 mixed-phase $\mathrm{TiO}_{2}$ using EPR. The Journal of Physical Chemistry B 2003, 107 (19), 4545-4549.

43. Xiang, Q.; Yu, J.; Wong, P. K. Quantitative characterization of hydroxyl radicals produced by various photocatalysts. Journal of Colloid and Interface Science 2011, 357 (1), 163-167.

44. Wu, N.; Wang, J.; Tafen, D. N.; Wang, H.; Zheng, J. G.; Lewis, J. P.; Liu, X.; Leonard, S. S.; Manivannan, A. shape-enhanced photocatalytic activity of single-crystalline anatase $\mathrm{TiO}_{2}(101)$ nanobelts. Journal of the American Chemical Society 2010, 132 (19), 6679-6685.

45. Halliwell, B; Whiteman, H. Measuring reactive species and oxidative damage in vivo and in cell culture: how should you do it and what do the results mean? British Journal of Pharmacology 2004, 142 (2), 231-255.

46. Setsukinai, K. I.; Urano, Y.; Kakinuma, K.; Majima, H. J.; Nagano, T. Development of novel fluorescence probes that can reliably detect reactive oxygen species and distinguish specific species. International Journal of Biological Chemistry 2003, 278 (5), 3170-3175.

47. Tachikawa, T.; Majima, T. Single-molecule fluorescence imaging of $\mathrm{TiO}_{2}$ photocatalytic reactions. Langmuir 2009, 25 (14), 7791-7802.

48. Shenawi-Khalil, S.; Uvarov, V.; Kritsman, Y.; Menes, E.; Popov, I.; Sasson, Y. A new family of $\mathrm{BiO}(\mathrm{ClxBr} 1-\mathrm{x})$ visible light sensitive photocatalysts. Catalysis Communications 2011, 12 (12), 1136-1141. 
49. Xie, C.; Lovell, M. A.; Markesbery, W. R. Glutathione transferase protects neuronal cultures against four hydroxynonenal toxicity. Free Radical Biological and Medicine 1998, 25 (8), 979-988.

50. McKnight, J. N.; Tillman, E. S.; Sarry, L. R. Lewis Acid-Induced N-Methyleneamines as initiators in the synthesis of secondary amine-terminated polymers. Macromolecular Rapid Communication 2006, 27 (18), 1578-1583.

51. Carballal, S.; Radi, R.; Kirk, M. C.; Barnes, S.; Freeman, B. A.; Alvarez, B. Sulfenic acid formation in human serum albumin by hydrogen peroxide and peroxynitrite. Biochemistry 2003, 42 (33), 9906-9914.

52. Adewale, I. O.; Afolayan, A. Organ distribution and kinetics of glutathione transferase from african river prawn, macrobrachium vollenhovenii (Herklots). Aquatic Toxicology 2005, 71 (2), 193-202.

53. Olojo, R. O.; Xia, R. H.; Abramson, J. J. Spectrophotometric and fluorometric assay of superoxide ion using 4-chloro-7-nitrobenzo-2-oxa-1,3-diazole. Analytical Biochemistry 2005, 339 (2), 338-344.

54. Merritt, M. V.; Sawyer, D. T. Electrochemical studies of the reactivity of superoxide ion with several alkyl halides in dimethyl sulfoxide. The Journal of Organic Chemistry 1970, 35 (7), 2157-2159.

55. Diaz-Uribe, C. E.; Daza, M. C.; Martínez, F.; Paez-Mozo, E. A.; Guedes, C. L. B.; Di Mauro, E., Visible light superoxide radical anion generation by tetra(4-carboxyphenyl)porphyrin $/ \mathrm{TiO}_{2}$ : EPR characterization. Journal of Photochemistry and Photobiology A: Chemistry 2010, 215, (2-3), 172-178.

56. Brezova, V.; Gabcova, S.; Dvoranova, D.; Stasko, A., Reactive oxygen species produced upon photoexcitation of sunscreens containing titanium dioxide (an EPR study). Journal of Photochemistry and Photobiology B: Biology 2005, 79, (2), 121-134.

57. Kutala, V. K.; Parinandi, N. L.; Zweier, J. L.; Kuppusamy, P., Reaction of superoxide with trityl radical: implications for the determination of superoxide by spectrophotometry. Archives of Biochemistry and Biophysics 2004, (424), 81-88.

58. Gomes, A.; Fernandes, E.; Lima, J. L. F. C., Fluorescence probes used for detection of reactive oxygen species. Journal of Biochemical and Biophysical Methods 2005, 65, 45-80.

59. Wardman, P., Fluorescent and luminescent probes for measurement of oxidative and nitrosative species in cells and tissues: Progress, pitfalls, and prospects. Free Radical Biology and Medicine 2007, 43, 995-1022.

60. Jones, C. M.; Lawrence, A.; Wardman, P.; Burkitt, M. J., Electron paramagnetic resonance spin trapping investigation into the kinetics of glutathione oxidation by the superoxide radical: re-evaluation of the rate constant. Free Radical Biology and Medicine 2002, 32, (10), 982-990.

61. Gardner, J. M.; Aust, S. D., Quantification of hydroxyl radical produced during phacoemulsification. Journal of Cataract \& Refractive Surgery 2009, 35, 2149-2153.

62. Sato, T.; Koizumi, Y.; Taya, M. Photocatalytic deactivation of airborne microbial cells on $\mathrm{TiO}_{2}$-loaded plate. Biochemical Engineering Journal 2003, 14 (2), 149-152.

63. Marugan, J.; van Grieken, R.; Sordo, C.; Cruz, C. Kinetics of the photocatalytic disinfection of Escherichia coli suspensions. Applied Catalysis B: Environmental 2008, 82 (1-2), 27-36.

64. Horie, Y.; David, D. A.; Taya, M.; Tone, S. Effects of light intensity and titanium dioxide concentration on photocatalytic sterilization rates of microbial cells. Industry \& Engineering Chemistry Research 1996, 35 (11), 3920-3926. 
65. Severin, B. F.; Suidan, M. T.; Engelbrecht, R. S. Series-event kinetic model for chemical disinfection. Journal Environmental Engineering 1984, 110 (2), 430-439.

66. Nel, A.; Xia, T.; Madler, L.; Li, N. Toxic potential of materials at the nanolevel. Science 2006, 311 (5761), 622-627.

67. Diebold, U. The surface science of titanium dioxide. Surface Science Report 2003, 48 (5-8), 53-229.

68. Yan, M.; Chen, F.; Zhang, J.; Anpo, M. Preparation of controllable crystalline titania and study on the photocatalytic properties. The Journal of Physical Chemistry B 2005, 109 (18), 8673-8678.

69. Tetsuro, K.; Yasuhiro, K.; Hiroaki, T.; Noboru, T.; Junji, N.; Seishiro, I. A patterned $\mathrm{TiO}_{2}$ (anatase) $/ \mathrm{TiO}_{2}$ (rutile) bilayer-type photocatalyst: effect of the anatase/rutile junction on the photocatalytic activity. Angewandte Chemie International Edition 2002, 41 (15), 2811-2813.

70. Dai, K.; Peng, T.; Chen, H.; Liu, J.; Zan, L. Photocatalytic degradation of commercial phoxim over la-doped $\mathrm{TiO}_{2}$ nanoparticles in aqueous suspension. Environmental Science \& Technology 2009, 43 (5), 1540-1545.

71. Jung-wook, S.; Heawon, C.; Mi-yun, K.; Jeonggi, L.; In-hong, C.; Jinwoo, C. Development of water-soluble single-crystalline $\mathrm{TiO}_{2}$ nanoparticles for photocatalytic cancer-cell treatment. Small 2007, 3 (5), 850-853.

72. Tanaka, K.; Capule, M. F. V.; Hisanaga, T. Effect of crystallinity of $\mathrm{TiO}_{2}$ on its photocatalytic action. Chemical Physics Letters 1991, 187 (1-2), 73-76.

73. Ding, Z.; Lu, G. Q.; Greenfield, P. F. Role of the crystallite phase of $\mathrm{TiO}_{2}$ in heterogeneous photocatalysis for phenol oxidation in water. The Journal of Physical Chemistry B 2000, 104 (19), 4815-4820.

74. Serpone, N. Relative photonic efficiencies and quantum yields in heterogeneous photocatalysis. Journal of Photochemistry and Photobiology A: Chemistry 1997, 104 (1-3), 1-12.

75. Yan, G.; Chen, J.; Hua, Z., Roles of $\mathrm{H}_{2} \mathrm{O}_{2}$ and $\mathrm{OH}$ radical in bactericidal action of immobilized $\mathrm{TiO}_{2}$ thin-film reactor: An ESR study. Journal of Photochemistry and Photobiology A: Chemistry 2009, 207, (2-3), 153-159.

76. Rincón, A. G.; Pulgarin, C. Effect of $\mathrm{pH}$, inorganic ions, organic matter and $\mathrm{H}_{2} \mathrm{O}_{2}$ on E. coli $\mathrm{K} 12$ photocatalytic inactivation by $\mathrm{TiO}_{2}$ : Implications in solar water disinfection. Applied Cataysis B: Environmental 2004, 51 (4), 283-302.

77. Cho, M.; Chung, H.; Choi, W.; Yoon, J., Different inactivation behaviors of MS-2 phage and Escherichia coli in $\mathrm{TiO}_{2}$ photocatalytic disinfection. Applied and Environmental Microbiology 2005, 71, (1), 270-275.

78. Wang, W.; Zhang, L.; An, T.; Li, G.; Yip, H.-Y.; Wong, P.-K., Comparative study of visible-light-driven photocatalytic mechanisms of dye decolorization and bacterial disinfection by B-Ni-codoped $\mathrm{TiO}_{2}$ microspheres: The role of different reactive species. Applied Catalysis B: Environmental 2011, 108-109, (0), 108-116.

79. Leung, T. Y.; Chan, C. Y.; Hu, C.; Yu, J. C.; Wong, P. K., Photocatalytic disinfection of marine bacteria using fluorescent light. Water Research 2008, 42, (19), 4827-4837.

80. Caballero, L.; Whitehead, K. A.; Allen, N. S.; Verran, J., Inactivation of Escherichia coli on immobilized $\mathrm{TiO}_{2}$ using fluorescent light. Journal of Photochemistry and Photobiology A: Chemistry 2009, 202, (2-3), 92-98. 
81. Wang, W.; Zhang, L.; An, T.; Li, G.; Yip, H.-Y.; Wong, P.-K., Comparative study of visible-light-driven photocatalytic mechanisms of dye decolorization and bacterial disinfection by B-Ni-codoped $\mathrm{TiO}_{2}$ microspheres: The role of different reactive species. Applied Catalysis B: Environmental 2011, 108-109, (0), 108-116.

82. Furman, O.; Laine, D. F.; Blumenfeld, A.; Teel, A. L.; Shimizu, K.; Cheng, I. F.; Watts, R. J., Enhanced reactivity of superoxide in water-solid matrices. Environmental Science \& Technology 2009, 43, (5), 1528-1533.

83. Kiwi, J.; Nadtochenko, V., Evidence for the mechanism of photocatalytic degradation of the bacterial wall membrane at the $\mathrm{TiO}_{2}$ interface by ATR-FTIR and laser kinetic spectroscopy. Langmuir 2005, 21, (10), 4631-4641.

84. Chen, F.; Yang, X.; Xu, F.; Wu, Q.; Zhang, Y., Correlation of photocatalytic bactericidal effect and organic matter degradation of $\mathrm{TiO}_{2}$ Part I: observation of phenomena. Environmental Science \& Technology 2009, 43, (4), 1180-1184.

85. Ireland, J. C.; Klostermann, P.; Rice, E. W.; Clark, R. M., Inactivation of Escherichia coli by titanium dioxide photocatalytic oxidation. Applied and Environmental Microbiology 1993, 59, (5), 1668-1670.

86. Rengifo-Herrera, J. A.; Kiwi, J.; Pulgarin, C., N, S co-doped and N-doped Degussa P-25 powders with visible light response prepared by mechanical mixing of thiourea and urea. Reactivity towards E. coli inactivation and phenol oxidation. Journal of Photochemistry and Photobiology A: Chemistry 2009, 205, (2-3), 109-115.

87. Kim, J. Y.; Lee, C.; Sedlak, D. L.; Yoon, J.; Nelson, K. L., Inactivation of MS2 coliphage by Fenton's reagent. Water Research 2010, 44, (8), 2647-2653.

88. Dodd, N. J. F.; Jha, A. N., Titanium dioxide induced cell damage: A proposed role of the carboxyl radical. Mutation Research/Fundamental and Molecular Mechanisms of Mutagenesis 2009, 660, (1-2), 79-82. 